\title{
PRELIMINARY STUDY OF URANIUM FAVORABILITY OF THE WILCOX AND CLAIBORNE GROUPS (EOCENE) IN TEXAS
}

\section{BENDIX FIELD ENGINEERING CORPORATION}

Grand Junction Operations

Grand Junction, Colorado 81501

January 1978

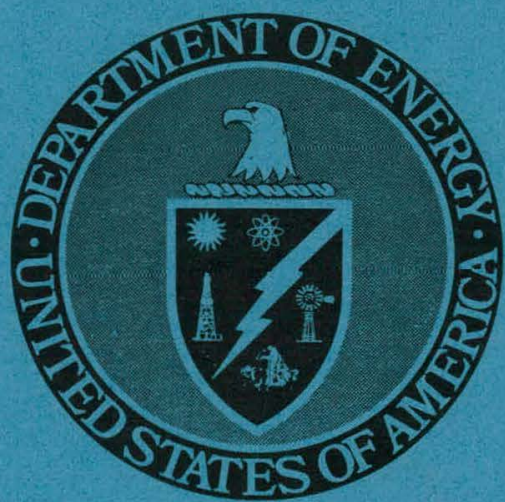

ISSUED BY THE U.S. DEPARTMENT OF ENERGY GRAND JUNCTION UHFICE UNDER CONTRACT NO. E(05-1)-1664 


\section{DISCLAIMER}

This report was prepared as an account of work sponsored by an agency of the United States Government. Neither the United States Government nor any agency Thereof, nor any of their employees, makes any warranty, express or implied, or assumes any legal liability or responsibility for the accuracy, completeness, or usefulness of any information, apparatus, product, or process disclosed, or represents that its use would not infringe privately owned rights. Reference herein to any specific commercial product, process, or service by trade name, trademark, manufacturer, or otherwise does not necessarily constitute or imply its endorsement, recommendation, or favoring by the United States Government or any agency thereof. The views and opinions of authors expressed herein do not necessarily state or reflect those of the United States Government or any agency thereof. 


\section{DISCLAIMER}

Portions of this document may be illegible in electronic image products. Images are produced from the best available original document. 
This report was prepared as an account of work sponsored by the United States Government. Neither the United States nor the United States Department of Energy, nor any of their employees, nor any of their contractors, subcontractors, or their employees, makes any warranty, expressed or implied, or assumes any legal liability or responsibility for the accuracy, completeness or usefulness of any information, apparatus, product or process disclosed, or represents that its use would not infringe privately owned rights. 
PRELIMINARY STUDY OF URANIUM FAVORABILITY

OF THE WILCOX AND CLAIBORNE GROUPS (EOCENE) IN TEXAS

W. P. Wilbert and C. J. Templain

\author{
BENDIX FIELD ENGINEERING CORPORATION \\ Grand Junction Operations \\ Grand Junction, Colorado 81501
}

January 1978

This report was prepared as an account of work sponsored by the United States Covemment Nerther United States nor the United States Departher the Energy, nor any of their employees, nor any of the contractors, subeontractors, or their employes, their any warranty, express or implied, or anuees, makes liability or responsibility for the accuracy, on any legal or usefulness of any information, acuracy, completeness process disclosed, or represention, apparatus, product or infringe privately owned rights.

PREPARED FOR THE U.S. ENERGY RESEARCH AND DEVELOPMENT ADMINISTRATION UNDER CONTRACT NO. EY-76-C-13-1664

ISSUED BY THE U.S. DEPARTMENT OF ENERGY, GRAND JUNCTION OFFICE 
THIS PAGE

WAS INTENTIONALLY

LEFT BLANK 
Summary . . . . . . . . . . . . . . . . . . . . 1

Introduction . . . . . . . . . . . . . . . . . . . . 2

Purpose .......................... . 2

Area investlgated . . . . . . . . . . . . . . . . . . 2

Procedures . . . . . . . . . . . . . . . . . . 2

Geology . . . . . . . . . . . . . . . . . . . . 5

Geologic history . . . . . . . . . . . . . . . 5

Structure ....................... . 5

Stratigraphy ....................... 8

Wilcox Group ...................... 8

Carrizo Sand .................... . 11

Reklaw Formation . . . . . . . . . . . . . . 11

Queen City Sand . . . . . . . . . . . . . 12

Weches Formation . . . . . . . . . . . . . 12

Sparta Sand . . . . . . . . . . . . . . . . . 13

Cook Mountain Formation... . . . . . . . . . . 13

Uranium Favorability . . . . . . . . . . . . . . . . . 14

Conclusions . . . . . . . . . . . . . . . . . . 14

Bibliography .......................... 17

Appendix A. Total and extractable $\mathrm{U}_{3} \mathrm{O}_{8}$ analytical

data from surface samples . . . . . . . . . . 21

Appendix B. Pathfinder element analyses of anomalous samples . . . . . . . . . . . 25

Appendix C. Gamma-ray logs with anomalous radioactivity

from Claiborne or Wilcox strata . . . . . . . . . 27 


\section{ILLUSTRATIONS}

Page

Figure 1. Index map ...................... 3

2. Average $\mathrm{CU}_{3} \mathrm{O}_{8}$ content in surface samples . . ...... . 4

3. Stratigraphic nomenclature used by Texas.

Bureau of Geology in outcrop mapping . . . . . . . . . . . 9

4. Typical electrical characteristics in

subsurface units . . . . . . . . . . . . 10

PLATES

Plate 1. Generalized surface geology and sample locations... . In pocket

2. Structure: Top of Wilcox Group ........... In pocket

3. Net sand: Lower Wilcox Group ............ In pocket

4. Net sand: Upper Wilcox Group ........... In pocket

5. Structure: Top of Carrizo Sand .......... In pocket

6. Isopach: Carrizo Sand ............ In pocket

7. Sand percentage: Carrizo Sand ......... In pocket

8. Maximum thickness of sand units: Carrizo Sand .. . . In,pocket

9. Structure: Top of Reklaw Formation . . . . . . In pocket

10. Isopach: Reklaw Formation ........... In pocket

11. Sand percentage: Reklaw Formation ......... In pocket

12. Maximum thickness of sand units: Reklaw

Formation . . . . . . . . . . ... . . . In pocket

13. Isopach: Queen City Sand ............ In pocket

14. Sand percentage: Queen City Sand ......... In pocket

15. Maximum thickness of sand units: Queen

City Sand . . . . . . . . . . . . . . . . In pocket

16. Structure: Base of Sparta Formation......... In pocket 


\section{ILLUSTRATIONS (continued)}

$\underline{\text { Page }}$

P1ate 17. Isopach: Sparta Formation............. In pocket

18. Sand percentage: Sparta Formation . . . . . . . In pocket

19. Maximum thickness of sand units: Sparta

Formation . . . . . . . . . . . . . . . In pocket

\section{TABLES}

Table 1. Stratigraphic column and lithologic

descriptions of the Claiborne and Wilcox Groups . . . . . 6

2. Modal analysis of sample MAC-191 (quartz wacke) from the Wilcox undifferentiated, Selby County (Lab no. 21896) . . 15 
Rocks of the Wilcox and Claiborne Groups crop out in the Texas Gulf Coastal Plain and are represented by a series of sands and shales which reflect oscillation of the strandline. The Wilcox Group (lower Eocene), usually undifferentiated in Texas, consists of very fine sands and clays and abundant lignite. The Claiborne Group (middle Eocene) comprises, in ascending order, Carrizo Sand, Reklaw Formation (clay), Queen City Sand, Weches Formation (clay), Sparta Sand, Cook Mountain Formation (clay), and Yegua Formation (sand).

Fluvial systems of the Wilcox and Claiborne Groups exist in east Texas and trend perpendicular to the present coastline. In central Texas, sand bodies are parallel to the present coastline and are strand-plain, barrierbar systems. Since the time of deposition of the Queen City Sand, a significant fluvial sand buildup occurred in the area of the present Rio Grande embayment where the marine clays pinch out.

Known occurrences of mineral matter in the Wilcox and Claiborne (up to the Yegua) are limited to lignite (particularly in the Wilcox), cannel coal in the upper $\mathrm{Claiborne}$, and hydrocarbons throughout. No uranium mineralization is known, and no uranium is likely to be discovered in the Claiborne and Wilcox. Approximately 50 surface samples and many gamma-ray logs showed no significant anomalies. The sands are very good potential host rocks, but no uranium source was discovered. During deposition of the Wilcox and Claiborne Groups, there was no volcanism to serve as a source of uranium (as with the prolific occurrences in the younger rocks of south Texas); also, Precambrian crystalline rocks in the Llano uplift were not exposed. 


\section{INTRODUCTION}

This report presents the results of a preliminary study of the uranium favorability of lower and middle Eocene rocks in the Wilcox and Claiborne Groups in the Texas Gulf Coastal Plain. The project began October 1, 1976, and was completed March 1, 1977, by personnel of Bendix Field Engineering Corporation (BFEC) under the auspices of the U.S. Energy Research and Development Administration (ERDA).

\section{PURPOSE}

The purpose of this project was to determine (1) whether the area under investigation is sufficiently favorable for the occurrence of commercially significant concentrations of uranium to warrant further investigation, and (2) if it is, what methods can best be employed to further evaluate the area:

\section{AREA INVESTIGATED}

Rocks of the Wilcox and Claiborne Groups (Eocene) crop out in areas covered in the Laredo, Crystal City, San Antonio, Seguin, Austin, Waco, Palestine, Dallas, Tyler, and Texarkana $2^{\circ}$ quadrangles (Bureau of Economic Geology). The project area extends downdip to the approximate position of the $-5,000 \mathrm{ft} \mathrm{msl}$ structure contour on the top of the Claiborne Group; some regions shown on the McAllen, Corpus Christi, Beeville, Houston, and Beaumont quadrangles are included in the project area (Fig. 1). 'l'he entire project area includes parts or all of 91 counties and encompasses about $200,000 \mathrm{sq} \mathrm{mi}$.

\section{PROCEDURES}

Relevant 1iterature and maps were reviewed. Outcrop samples (P1. 1) were collected and analyzed by $B F E C$ for both fixed and leachable $\mathrm{U}_{3} \mathrm{O}_{8}$; these values are listed in Appendix $A$ and are graphically shown by stratigraph1c unit in Figure 2. Available logs of radioactivity were examined; anomalies are listed in Appendix B. Samples that showed anomalously high uranium content were analyzed for pathfinder elements. Also, several thin sections were prepared and examined. Selected clay samples were examined by $\mathrm{x}$-ray diffraction.

Data for subsurface sand maps were taken from. Fischer and McGowen (1967), Jones and others (1976), and Payne (1968, 1972, 1975). The maps are based on loose well spacing (approximately one well for every $5 \mathrm{sq} \mathrm{mi}$ ). Only the stratigraphic units that are mainly sand were mapped by these authors. An arbitrary depth limit of $-5,000 \mathrm{ft} \mathrm{ms} 1$ was used in the subsurface mapping. Surface samples were collected from all units, but mostly from the more sandy unfts. 


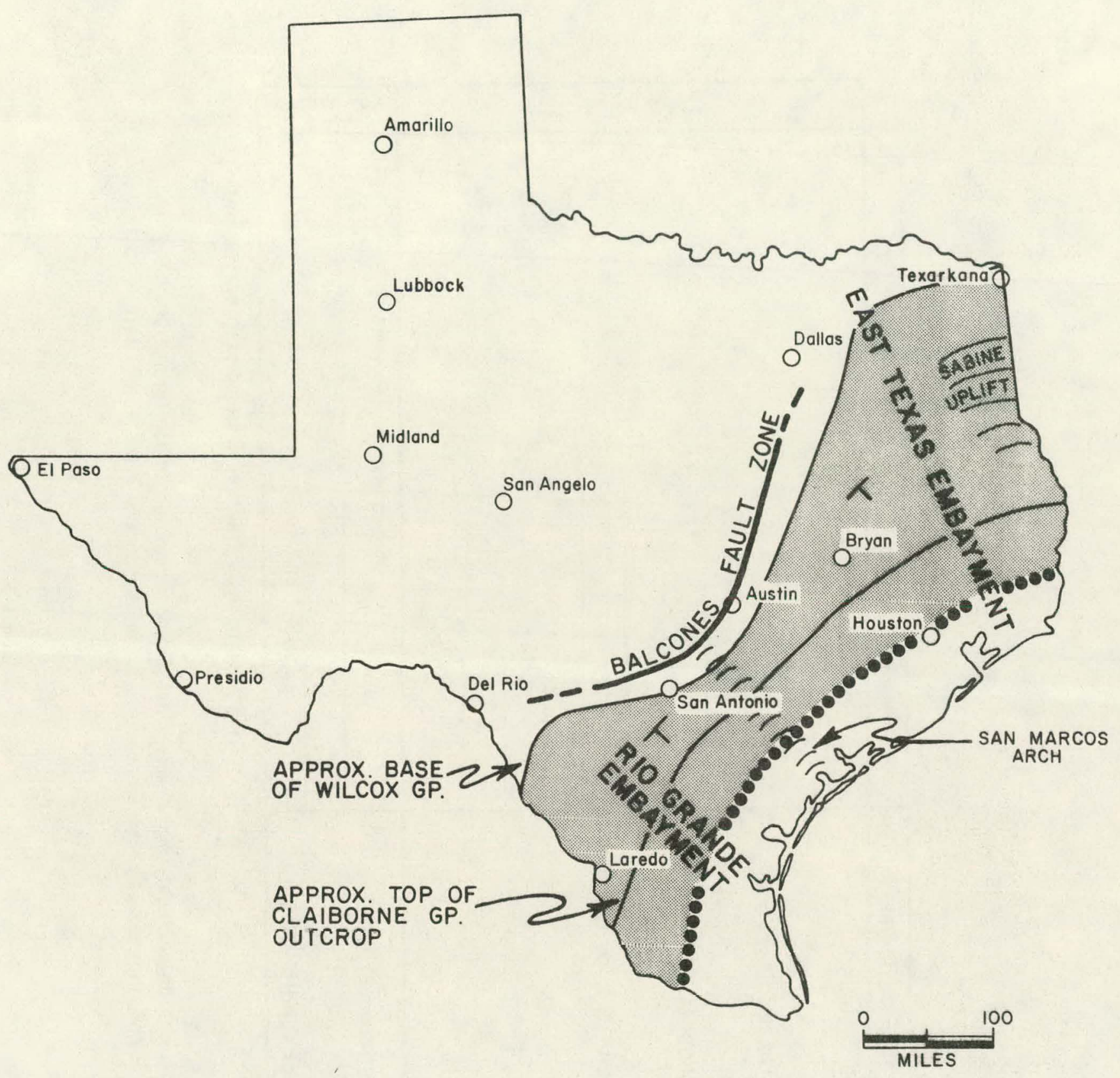

Project Area

Approximate position of $-5000^{\prime}$ structure contour on top of Claiborne Group, the downdip limit of the project area

Figure 1. Index map. 


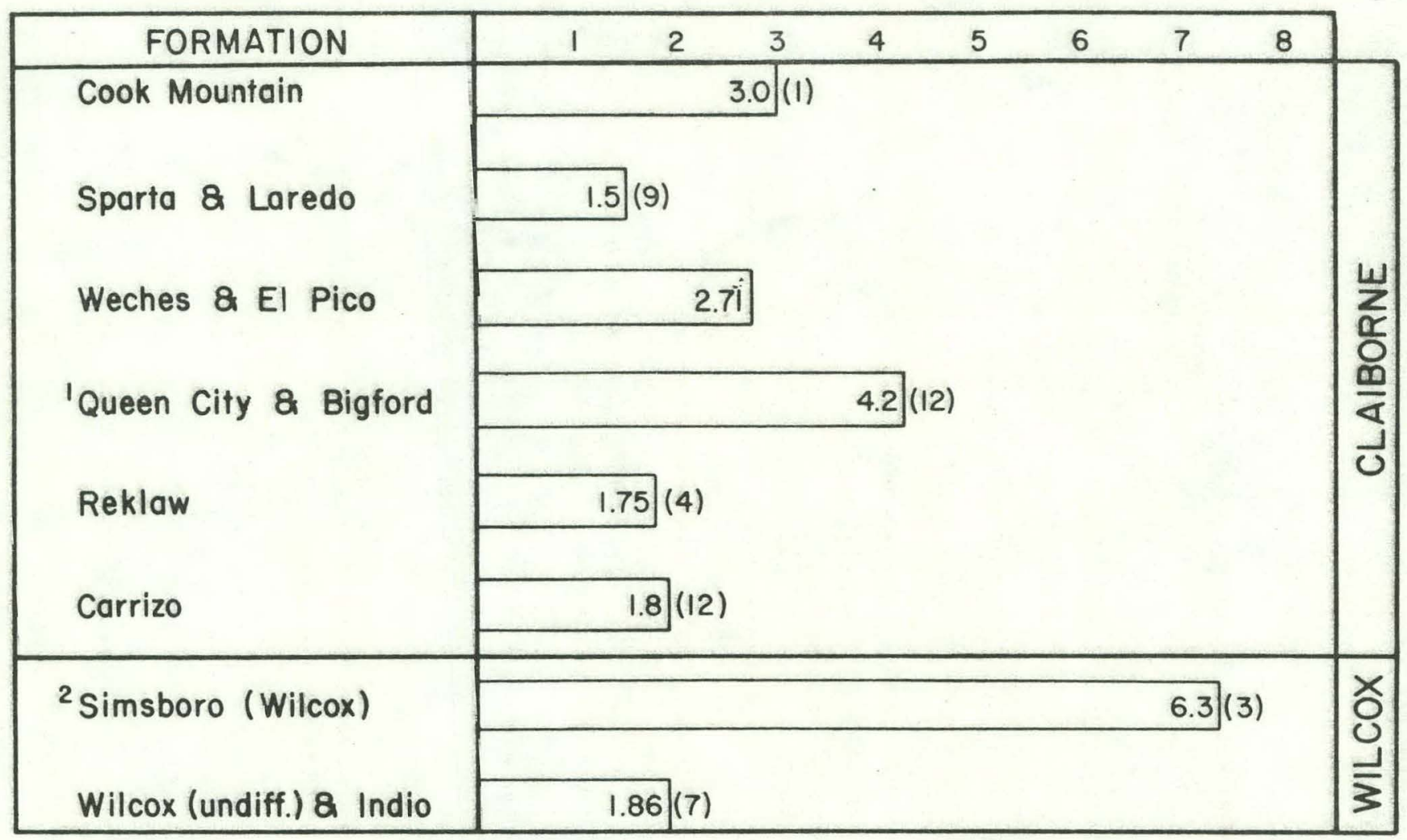

Mean ppm $\mathrm{U}_{3} \mathrm{O}_{8}$ (number of samples in parentheses)

I If one anomalously high Queen City sample is ignored, mean total $\mathrm{U}_{3} \mathrm{O}_{8}$ is 2.27 .

${ }^{2}$ If one anomalously high Simsboro sample is ignored, mean total $\mathrm{U}_{3} \mathrm{O}_{8}$ is 1.0 .

Figure 2. Average $\mathrm{cU}_{3} \mathrm{O}_{8}$ content of surface samples. 
GEOLOGY

GEOLOGIC HISTORY

Geologic history of the Gulf Coastal Plain has been reviewed by numerous authors. Detailed tectonic studies'by Bornhauser (1958) and a regional compilation by Murray (1961) are the most comprehensive. The sediments of the Wilcox and Claiborne Groups (Eocene) represent several cycles of transgression and regression (Lowman, 1949). Coarser clastic sediments (sands) were deposited during the regressions and are generally of continental origin. These progradational sand units are separated by marine clay. The clay/sand cyclicity of the lithologies of the stratigraphic units are described in Table 1. Volcanic rocks and shallow intrusions along the Balcones fault zone are of Cretaceous and earliest Tertiary age. Volcanism apparently ceased near the beginning of Wilcox deposition and began again near the end of Claiborne deposition to continue through the Miocene Epoch and act as a source for uranium deposits in south Texas (Eargle and others, 1975). The source of the later volcanism is believed by most workers to have been in West Texas and (or) northern Mexico (W. E. Galloway, 1976, personal commun.).

There are few lithologically pure rocks in either.the Wilcox or the Claịborne. Most sands contain some clay, and most clays contạin minor amounts of sand and silt.

\section{STRUCTURE}

Major structural features of the Texas Gulf Coastal Plain are shown on Figure 1. Rocks that crop out in the coastal plain generally dip homoclinally coastward less than $1^{\circ}$. The East Texas and Rio Grande embayments are separated by the San Marcos arch, which trends southeastward from the Llano uplift through Guadalupe and Caldwell Counties. Presence of the embayments and the arch have affected lithologies and thicknesses of sediments.

Sedimentary units are generally thicker in the embayments. Thickening is especially evident in Cretaceous rocks, and Tertiary rocks are less affected. The embayments and the Sabine uplift at the eastern edge of the project area predate the Wilcox and Claiborne strata, although the Sabine uplift may have been rejuvenated during the Tertiary Period. Large areas of Precambrian crystalline rocks are exposed on the Llano uplift, about $70 \mathrm{mi}$ northwest of Austin, but there is no evidence that the crystalline rocks were exposed prior to Miocene time, when there was major movement along the Balcones fault zone (Young, 1962, p. 104). Thus, the Precambrian rocks were not a source for the clastic sediments in the Wilcox and Claiborne Groups.

The project area is transected by numerous faults. The faults are mostly normal, down-to-the-coast, growth faults that form hydrocarbon traps and disrupt the ground-water flow. They are generally aligned parallel to the present coastline, except in Anderson and the surrounding counties where they are associated with salt domes in the East Texas salt basin. Few of these faults are exposed at the surface; they are recognized, in most cases, by loss of section in the many hydrocarbon and water wells and, in a few cases, by disruption of vegetation belts. 
TABLE 1. STRATIGRAPHIC COLUMN AND LITHOLOGIC DESCRIPTIONS OF THE CLAIBORNE AND WILCOX GROUPS (Descriptions and thicknesses based on section exposed in central Texas and augmented where necessary; adapted from Bur. Econ. Geology Geol. Atlas of Texas sheets)

\begin{tabular}{|c|c|c|}
\hline Group & Formation & Lithology and thickness \\
\hline \multirow{7}{*}{ 四 } & Yegua & $\begin{array}{l}\text { Sandstone, clay, and lignite, } 750-1,000 \mathrm{ft} \\
\text { thick (not studied in this project). }\end{array}$ \\
\hline & Cook Mountain & $\begin{array}{l}\text { Mostly clay, variably glauconitic and (or) } \\
\text { sandy, small concretions common, marine mega- } \\
\text { fossils and microfossils abundant; near Brazos } \\
\text { River, a very richly fossiliferous glauconite } \\
\text { tongue is called the Stone City Formation; } \\
\text { thickness of Cook Mountain near Austin is } \\
200-300 \mathrm{ft} \text { thick. }\end{array}$ \\
\hline & Sparta & $\begin{array}{l}\text { Quartz sand, very fine- to fine-grained, well } \\
\text { sorted, micaceous; silty clay partings; locally } \\
\text { carbonaceous, laminated; 150-200 ft thick. }\end{array}$ \\
\hline & Weches & $\begin{array}{l}\text { Clay and sand, in part marly; quartz sand common } \\
\text { interbedded silty glauconitic clay; brown to darl } \\
\text { green, weathers red; locally forms layers of } \\
\text { ironstone; marine megafossils and microfossils } \\
\text { abundant; approximately } 50 \mathrm{ft} \text { thick. }\end{array}$ \\
\hline & Direen Gity & $\begin{array}{l}\text { Fine-grained quartz sand, locally carbonaceous; } \\
\text { thin interbeds of sandy, glauconitic clay; out- } \\
\text { crups usually show prominent cross-beddsng; } \\
\text { weathers red and white mottled; approximately } \\
200 \mathrm{ft} \text { thick. }\end{array}$ \\
\hline & Rcklaw & $\begin{array}{l}\text { Clay and sand, glauconitic, carbonaceous in } \\
\text { upper part; ironstone lentils and marine mega- } \\
\text { fossils in east Texas; muscovite in Gregg County } \\
35 \mathrm{ft} \text { thick near Louisiana boundary but thickens } \\
\text { slightly to southwest and is } 80 \mathrm{ft} \text { thick south } \\
\text { in Austin; in the Rio Grande embayment, merges } \\
\text { with Bigford Formation a terrigenous sand and } \\
\text { silt. }\end{array}$ \\
\hline & Carrizo & $\begin{array}{l}\text { Sandstone, fine to coarse grained, poorly sorted } \\
\text { friable, noncalcareous, thickly bedded to cross- } \\
\text { bedded; contains carbonaceous trash; } 100 \mathrm{ft} \\
\text { thick; forms ridges (particularly in East Texas) } \\
\text { covered with oak; pinches out near the boundary } \\
\text { between Morris and Titus Counties. }\end{array}$ \\
\hline
\end{tabular}


TABTE 1. (continued)

\begin{tabular}{|c|c|c|}
\hline Group & Formation & Lithology and thickness \\
\hline 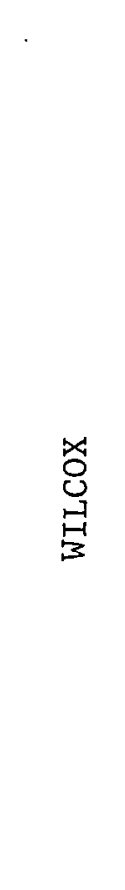 & 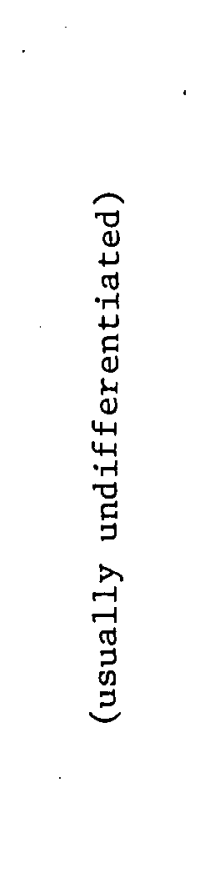 & $\begin{array}{l}\text { Sandstone and mudstone, brown to yellowish-brown, } \\
\text { locally lignitic and cross-bedded; sandstone, } \\
\text { both lenticular and in thin beds, very fine- to } \\
\text { medium-grained sand, moderately well sorted, } \\
\text { undivided in most places; divided in places } \\
\text { north of Colorado River into Hooper clay, Sims- } \\
\text { boro sand, Calvert Bluff clay, in ascending } \\
\text { order; Simsboro, where recognized, is mostly } \\
\text { sand with some mudstone and mudstone conglom- } \\
\text { erate, fine to coarse grained, generally well } \\
\text { sorted and cross-bedded; Calvert Bluff contains } \\
\text { most commercial lignite deposits (Kaiser, 1974); } \\
\text { entire group is about 2,000 ft thick in the } \\
\text { Austin area; maintains comparable thickness to } \\
\text { the east (within Texas) and has abundant carbon- } \\
\text { aceous trash and some marine megafossils; called } \\
\text { the Indio Formation in Rio Grande embayment } \\
\text { where it is fine-grained sand, shale, siltstone, } \\
\text { and lignite and 440 ft thick; the Simsboro, } \\
\text { which pinches out in Freestone County (Bur. } \\
\text { Econ. Geology, 1968), is as much as } 300 \text { ft thick. }\end{array}$ \\
\hline
\end{tabular}


Jurassic salt is thick enough to have formed domes only in the East Texas salt basin, where piercement of the Wilcox and Claiborne strata is common (P1. 2). Salt tectonics are not important elsewhere in the project area.

The Sabine uplift is present at the eastern margin of the project area (Fig. 1). Basement rocks are located in this area at shallow depths as indicated by well data in eastern Texas and southern Arkansas and by regional gravity maxima. The uplift appears to have been a positive feature since late Paleozoic time, although it was intermittently inundated during the Mesozoic and Cenozoic Eras (Murray, 1961). There is little topographic expression of the uplift; it is marked by an inlier of Wilcox strata, mostly in Panola County (P1. 1).

\section{STRATIGRAPHY}

The stratigraphic nomenclature used in outcrop mapping by the Texas Bureau of Economic Geology is shown on Figure 3 and is used in this report. Characteristic electric log (E-log) curves of the same units in the subsurface are shown on Figure 4 for the section northeast and southeast of the San Marcos arch.

\section{Wilcox Group}

The Wilcox Group represents deposition during the first major cycle of alluviation and delta formation in the Gulf province (Lowman, 1949, p. 1987). The Wilcox sands are divided downdlp by a wedge of marine shale into a lower sand, a middle shale, and an upper sand. Structure contours on the top of the Wilcox Group are shown on Plate 2. Depositional systems of the lower Wilcox have been studied, mainly in the subsurfacc, using E-1.ngs by Fisher and McGowen (1967). The1r net-sand map, which is reproduced here as Plate 3, shows an extensive fluvial-deltaic system northeast of the San Marcos arch, and lagoons and barrier bars southeast of the arch. The middle Wilcox shale is continuous along strike (Jones and others, 1976), but it does not crop out. Thus the term "Wilcox undivided" is usually used for describing rocks at and near the outcrop.

The upper Wilcox is a fluvial-dellaic sand that differs from the lower Wilcox in detail only. The upper Wilcox has been less studied than the lower Wilcox. Net-sand isoliths (P1. 4) show that the thickest sands are southwest of the San Marcos arch.

The Wilcox Group on outcrop thickens northeastward from about $500 \mathrm{ft}$ in Zavala County, near the Rio Grande, to 3,000 ft in Milam County. From Milam County northeastward, it thins to about 2,000 ft in Nacogdoches County (Jones and others, 1976). Southeastward (downdip), the group thickens to more than $5,000 \mathrm{ft}$ at the downdip limit of the project area. This thickening is evidenced (1) by normal thickening into the Gulf basin and (2) by inclusion of the middle Wilcox marine shale wedge. A similar pattern is present in all sands of the Claiborne Group. 


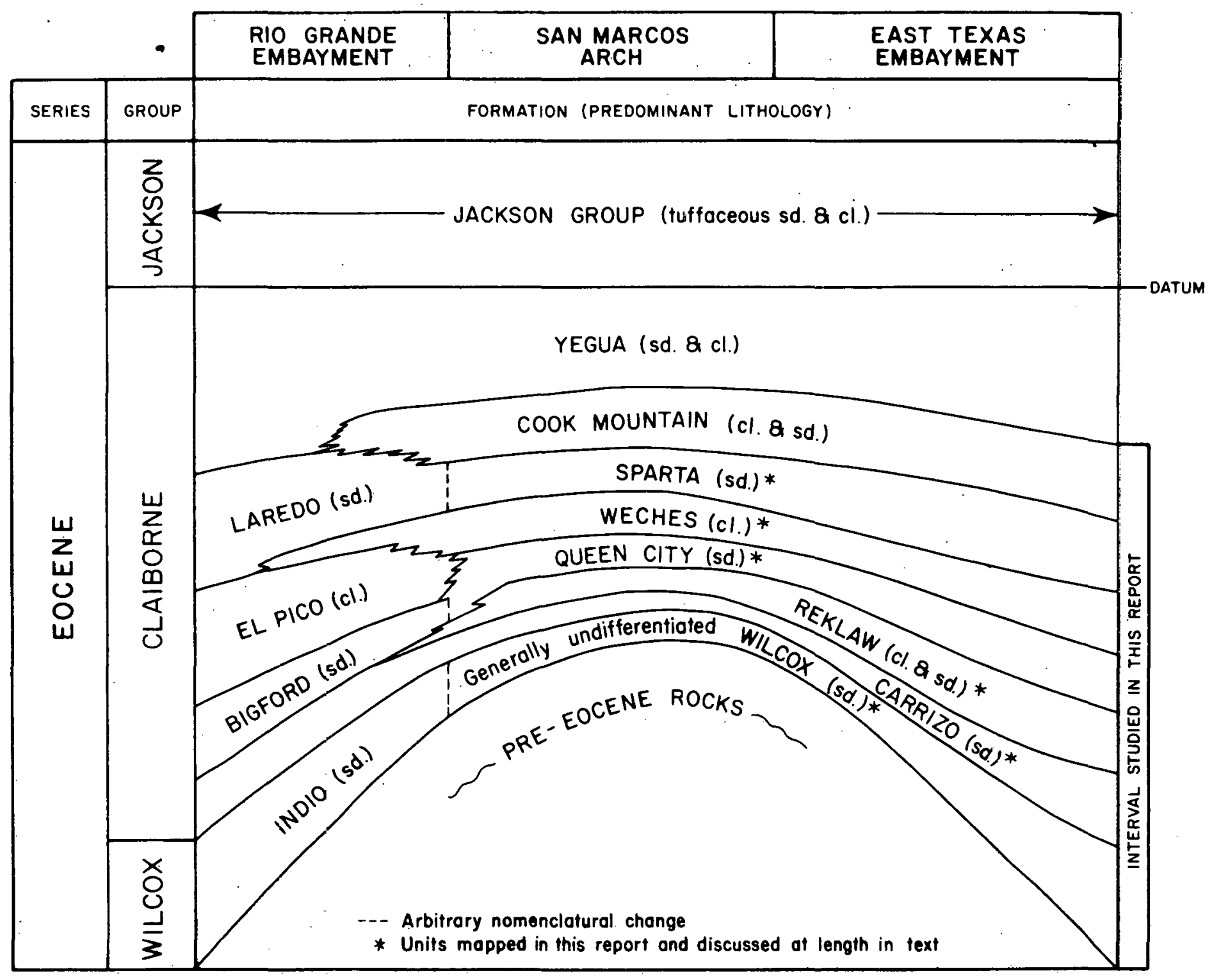

Figure 3. Stratigraphic nomenclature used by Texas Bureau of Economic Geology in outcrop mapping. 
*58-56-702

Bostrop County

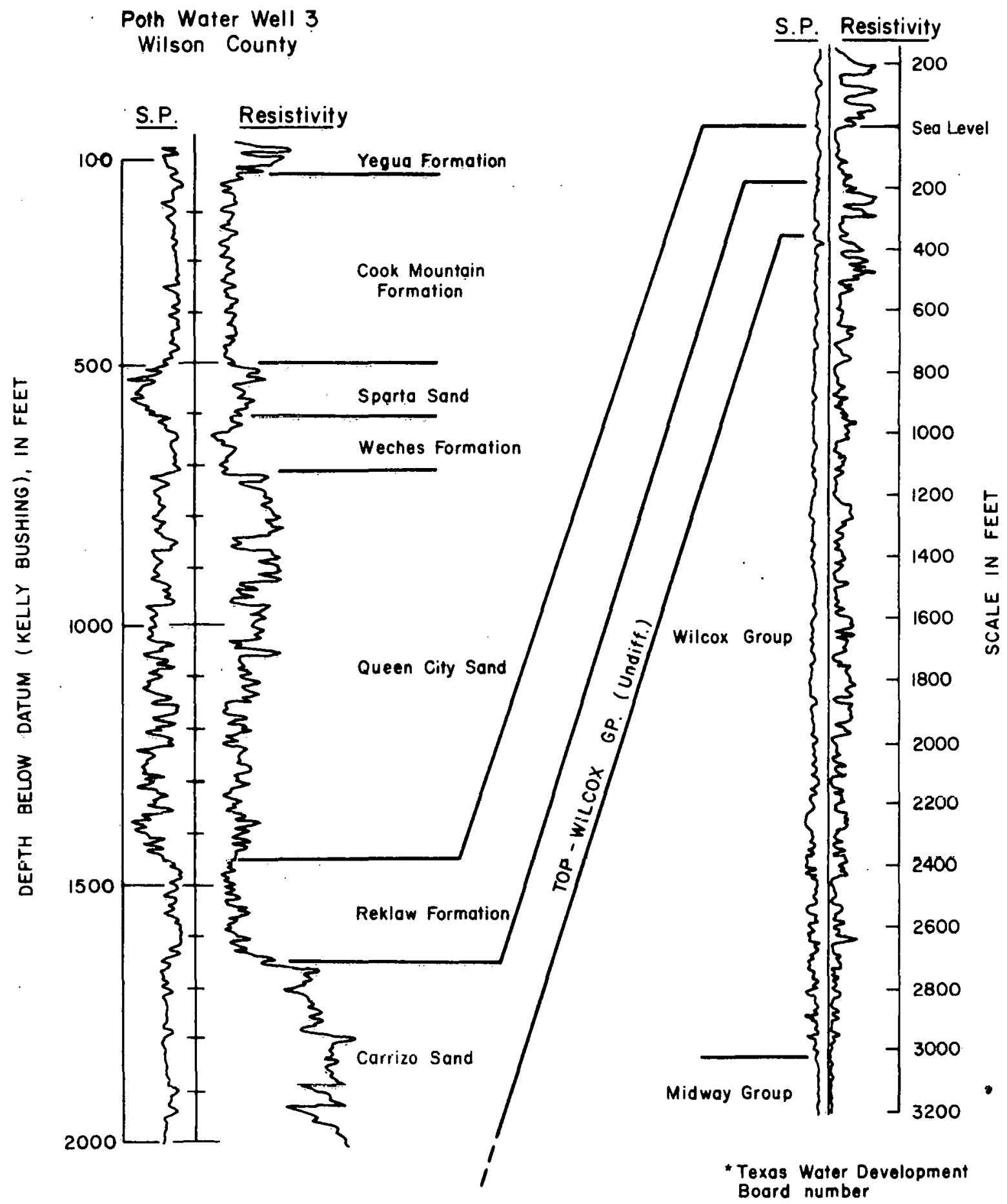

NOTE: Different depth \& electrical scales on each well.

Figure 4. Typical electrical characteristics of subsurface units (Poth well modified after Eargle, 1968; Bastrop County oil well modified aftcr Follett, 1970). 


\section{Carrizo Sand}

The Carrizo Sand is a massive to cross-bedded quartzose sand. It is one of the most prolific aquifers of the Gulf Coastal Plain and is also one of the most lithologically consistent units in the Claiborne Group. It consists of 80 to 100 percent sand-sized particles. It can be traced for several hundred miles from a feather edge north of the Sabine uplift southwest into the Rio Grande embayment, where it is more than $1,000 \mathrm{ft}$ thick on outcrop (P1. 6), thence across the Rio Grande (Eargle, 1968, p. D7) with little lithologic change. Structure contours on the top of the Carrizo are shown on Plate 5. The Carrizo can be traced 40 to $50 \mathrm{mi}$ downdip from the outcrop. The authors believe the thick sands in south Texas, shown on Plate 8 , are longshore bars. Sand, thick in other units in south Texas, trends perpendicular to the coast and is believed to represent fluvial-deltaic systems. Guevara and Garcia (1972) interpreted some sands in the Queen City Formation to be longshore bars downcoast from fluvial-deltaic sediments in east Texas; the coastlineparallel thick sands in the Carrizo Formation are analogous to the Queen City sands.

There is a fairly well-developed fluvial-deltaic system in northeast Texas that centers around Leon County. It consists of thin carbonaceous clays (probably representing interdistributary bays) interbedded with extensive channel facies (P1s. 7, 8). Sands of the channel facies also contain some carbonaceous trash. The trash has apparently been leached from the outcrop because none was observed.

An interval of erosion may have occurred after deposition of the Wilcox and before deposition of the Carrizo. The basal Carrizo contains sma11 chert gravel and quartz sand in Bastrop County (site of surface samples MAC-027 and MAC-028; P1. 1; App. A). Eargle (1968) traced the Carrizo-Wilcox unconformity through Texas from the Carrizo pinchout in east Texas to the Rio Grande and beyond. However, downdip the Carrizo cannot be distinguished from the Wilcox. In this report, the Carrizo is considered to be the basal unit of the Claiborne Group, as 1 t is in most of the 1iterature (Murray, 1961).

Average outcrop thickness of the Carrizo in the Freestone County area is $95 \mathrm{ft}$ (Guyton and others, 1972). Southwestward to Bastrop County, it thickens to $250 \mathrm{ft}$ and to a maximum of aboul $300 \mathrm{ft}$ near its type locality near Carrizu Springs in Dimmit County.

On outcrop, the Carrizo is easily distinguished from the underlying Wilcox by red oxidation of iron minerals in the Carrizo. The red coloration, in fact, is a characteristic of all sands of the Claiborne Group.

\section{Reklaw Formation}

The Reklaw Formation is dominantly marine clay that is glauconitic in many places (P1.9). Although dominantly clay, it contains lenses of sand as much as $175 \mathrm{ft}$ thick (P1. 12) in the subsurface near the Wilson-Karnes county line (P1s. 10, 11). 
Southwestward along strike, the clayey lithology and marine character of the Reklaw persist to about the Frio River in Frio County. Southwest from there, the clays are thinner and interfinger with sands (Eargle, 1968, p. D10). In the Rio Grande embayment, the marine clay of the Reklaw wedges into the fluvial sands of the Bigford Formation.

Thickness of the Reklaw on the outcrop ranges from 30 to $130 \mathrm{ft}$ in eastern Texas, from 30 to $300 \mathrm{ft}$ in Wilson County, and from 600 to $800 \mathrm{ft}$ downdip in Webb County. Here, the Reklaw and the overlying Queen City Sand are mapped as the Bigford Formation (Bur. Econ. Geology, 1976).

\section{Queen City Sand}

The Queen City Sand is a sandy, sparsely fossiliferous section between the Reklaw and the Weches (Table 1). According to Calendar (1957), the Queen City, in central Texas, contains the same metamorphic suite as the Carrizo but is less abundant.

The isopach map (P1. 13) shows the maximum thickness of the Queen City Sand to be in extreme southwest Texas. Depositional systems of the Queen City were studied by Guevara and Garcia (1972). Their sand isolith map (1972, Figs. 12a, 12b) reflects a sand dispersal pattern similar to that shown in the Wilcox by Fisher and McGowen (1967), with the exception that a major buildup of sand for the Queen City was deposited by the paleo-Rio Grande in extreme southwest Texas. This sand buildup in Zavala and Webb Counties is also reflected in Payne's (1972) sand percentage map, reproduced here as Plate 14. Plate 15 shows the trend and maximum thickness of Queen City Sand units. As a result. of the sand buildup in southwest Texas, the strand-plain, barrier-bar facies of the Queen City is restricled to central Texas (Guevara and Garcia, 1972), basically near the crest of and on either side of the San Marcos arch.

Fluvial-deltaic sands in the quin City reflecl lle earliest sand deposition of the paleo-Rio Grande river system. The influence of the paleo-Rio frande may be seen on sand percentage maps of the Queen City and subsequent Claiborne units. The influx of sand reflects uplift in ccntral Arizona and Ncw Mexicu. Volcaniclastics did not appear in Texas sedimenls until latc Eocene Lime (Jackson Group).

\section{Weches Formation}

In Texas, the Weches Formation is a thin marine unit. It is composed mostly of clay with some siltstones and is characterized throughout Texas by much glauconite. Locally in outcrop, the Weches contains some sandy 1 enses but not as much as the Reklaw Formation. Most outcrops east of the San Marcos arch contain marine fossils, dominantly mollusks. Plate 16 shows that no salt diapirism affects the Weches Formation.

The Weches thickens to the southwest from about $50 \mathrm{ft}$ in Cherokee County (Guyton and others, 1972) to about $100 \mathrm{ft}$ in Bastrop County (Follett, 1970). At the east margin of the Rio Grande embayment, the formation becomes 
gypsiferous and carbonaceous. Southwest of the Frio River, the Weches is generally nonmarine and cannot be distinguished from the Queen City on well. logs because the two formations merge laterally into the E1 Pico Clay (Eargle, 1968). In Dimmitt County, the El Pico Clay is $700 \mathrm{ft}$ thick, and it thickens toward the Rio Grande to a reported thickness of more than 1,100 ft (Eargle, 1968). Six cannel coal mines are near the contact between the El Pico and Bigford in Webb County just north of Laredo. Sands in the El Pico are rare and thin.

\section{Sparta Sand}

The Sparta Sand in the subsurface is one of the most easily recognized units in the Claiborne Group (Eargle, 1968). On outcrop, the Sparta is easily mistaken for the Queen City or Carrizo, and it is virtually identical to other Claiborne sands in terms of petrography and sedimentary structures. The Sparta Sand is quartzose, hematitic, and commonly cross-bedded.

In east Texas, the Sparta consists mostly of very fine- to fine-grained quartz sand, clay, and silty clay that contains some lignite beds (Guyton and others, 1972). In central Texas it consists of fine- to medium-grained, loose to lightly cemented stratified sand beds that are separated by thin layers of clay and silt (Follett, 1970).

The Sparta thins southwestward across the state, from about $325 \mathrm{ft}$ in deltaic(?) lobes in southern Cherokee County to $200 \mathrm{ft}$ in Lee County and to less than $100 \mathrm{ft}$ in Webb County (PI. 17). In southern Webb County and southward, the upper part of the Claiborne Group (Laredo Formation) is mostly sand. This increased sand content reflects the increasing dominance of the paleoRio Grande depositional system (PI. 18).

The Sparta can be traced on E-logs as far as the Rio Grande (J. V. Quick, 1976, personal commun.), and Payne (1968) has mapped it. However, the clayey Cook Mountain Formation above the Sparta begins to reflect paleo-Rio Grande drainage and picks up sand and lignite. This formation is called the Laredo by the Texas Bureau of Economic Geology on its Laredo (1976) and Crystal CityEagle Pass sheets (1977). Thick sands in the Sparta Formation in east Texas (P1. 19) reflect fluvial-deltaic conditions similar to those in the Wilcox Group.

\section{Cook Mountain Formation}

The Cook Mountain Formation consists mostly of marine clay with a few beds of very fine sand (Eargle, 1968, p. D21). It is from 125 to $450 \mathrm{ft}$ thick across the state. The Laredo is formed southwest of where the Cook Mountain Formation interfingers with the Sparta. Although it was deposited nearshore, as evidenced by highly glauconitic sands (Eargle, 1968), the Cook Mountain retains its marine character.

The Cook Mountain does not crop out throughout most of Texas. Where it does crop out, it is onc of the most distinctive units in the Claiborne Group; it is buff to brown and resembles the marine clays of the Wilcox. The Cook Mountain Formation is overlain by the sandy. and lignitic Yegua Formation. 
URANIUM FAVORABILITY

Although suitable uranium host rocks exist at many places in the Wilcox and Claiborne Groups in Texas, there is no uranium source rock. In addition, there is no known uranium mineralization in the Wilcox or Claiborne Groups. Grutt (1972) has shown that tuffaceous sediments are often present in the section above the host sandstone or in the host rock itself. No such tuffaceous beds were found in the Wilcox and Claiborne section. G. D. Stanton (1976, personal commun.) noted small but measurable amounts of volcanic rock fragments in the lower Wilcox in Karnes County (subsurface). However, no sanidine, shards, or high-temperature mineralogic polymorphs were noted. Folk (1961) reported some evidence of volcanic material in the Wilcox and the Queen City. A possible volcanic source for the Wilcox is indicated by subhexagonal biotite, sphene, and apatite. Evidence for a possible volcanic source for the Queen City is the presence of subhexagonal biotite and apatite. However, this mineralogic suite does not preclude a plutonic source. Recent in-depth studies (Kaiser, 1974; Jones and others, 1976; Fisher and McGowen, 1967) of the Wilcox Group in Texas do not mention volcanism.

No evidence of volcanism contemporaneous with Wilcox or Claibrone sedimentation was detected during this study. Modal analysis of a sample representative of the Wilcox sandstone (Table 2) showed that most minerals could have had a plutonic or a sedimentary source. Thin-section studies and photomicrographs of several samples from the Wilcox did not reveal any sign of volcanic rocks, although the interstitial clay matrix comprises a fairly high percentage of the rock and could obscure some grains. The samples contain many unidentifiable rock fragments.

Past industry activity in the Wilcox and Claiborne Groups has failed to produce any reported uranium shows. However, there have been many exploration test wells.

Several surface samples of the undivided Wilcox and the prominent simshoro sand in Falls and Limestone Counties contain abundant lignitic material. Uranium assay of these samples, however, showed an average of only $1.0 \mathrm{ppm}$ uranium.

Twenty-eight gamma-ray logs (App. C) showed anomalies of at least $2 \mathrm{X}$ background. These are all minor and most are less than $3 \mathrm{X}$ background. No definite 5X background anomalies, an arbitrary cutoff point used by Grutt (1972), are known.

\section{CONCLUSIONS}

In summary, many units of the Wilcox and C1 aiborne Groups in Texas seem to be excellent host rocks for uranium. However, no source of uranium is known.

A few radioactivity anomalies appear on gamma-ray logs, but all are of low magnitude and indicate small anomalies at the same horizon. No outcrop samples contained anomalous amounts of uranium. 
TABLE 2. MODAL ANALYSIS OF SAMPLE MAC-191 (QUARTZ WACKE)* FROM THE WILCOX UNDIFFERENTIATED, SELBY COUNTY (LAB NO. 21896)

\begin{tabular}{lc}
\hline Niineral or component & Estimated percent \\
\hline Clay matrix & 44 \\
Quartz & 37 \\
Chert & 7 \\
Clay clasts & 5 \\
Metamorphic rock & \\
fragments & 3 \\
Muscovite & 1 \\
K-feldspar & 1 \\
Opaque minerals & 1 \\
Plagioclase & tr \\
Tourmaline* & tr
\end{tabular}

*Quartz wacke as defined by Williams and others, 1954. 
None of the sediments contain a significant percentage of volcanic material, which is generally believed to be the source of uranium in sedimentary deposits. More important perhaps, favorable loci for deposits, such as lignitic concentrations, are barren in the Claiborne and Wilcox Groups. Lignite samples from the Wilcox Group should be periodically checked for anomalous radioactivity and the occurrence of uranium minerals.

Mapping of sand trends in the Cook Mountain - Laredo - Sparta interval in the Rio Grande embayment was beyond the scope of a preliminary investigation, but it could be fruitful for the uranium prospector. 


\section{BIBLIOGRAPHY}

Blair, R. G., 1959, Preliminary report on radioactive mineral deposits in the Gulf Coastal Plain of Texas and Louisiana, north and east of the Guadalupe River: U.S. Atomic Energy Comm. Tech. Memo. Rept. TM-D-5-2, Open-File Rept., 15 p., 11 figs.

Bornhauser, Max, 1958, Gulf Coast tectonics: Am. Assoc. Petroleum Geologists Bull., v. 42, p. 339-370.

Bureau of Economic Geology, 1965, Tyler sheet, geologic atlas of Texas, Barnes, V. E., proj. director: Texas Univ. Austin Bur. Econ. Geology Geol. Quad. Map, scale 1:250,000.

1966, Texarkana sheet, geologic atlas of Texas, Barnes, V. E., proj. director: Texas Univ. Austin Bur. Econ. Geology Geol. Quad Map, scale $1: 250,000$.

1968, Palestine sheet, geologic atlas of Texas, Barnes, V. E., proj. director: Texas Univ. Austin Bur. Econ. Geology Geol. Quad. Map, scale $1: 250,000$.

1970, Waco sheet, geologic atlas of Texas, Barnes, V. E., proj. director: Texas Univ. Austin Bur. Econ. Geology Geol. Quad. Map, scale 1:250,000.

1972, Dallas sheet, geologic atlas of Texas, Barnes, V. E., proj. director: Texas Univ. Austin Bur. Econ. Geology Geol. Quad. Map, scale $1: 250,000$.

1974a, San Antonio sheet, geologic atlas of Texas; Barnes, V. E., proj. director: Texas Univ. Austin Bur. Econ. Geology Geol. Quad Map, scale $1: 250,000$.

$1.974 \mathrm{~h}$, Seguin sheet, geologic atlas of..Texas; Barnes, V. E., proj. director: Texas Univ. Austin Bur. Econ. Geology Geol. Quad. Map, scale $1: 250,000$.

$\therefore 1974 \mathrm{c}$, Austin sheet, geologic atlas of Texas; Barnes, V. E., proj. director: Texas Univ. Austin Bur. Econ. Geology Geol. Quad. Map, scale $1: 250,000$.

1976a, Laredo sheet, geologic atlas of Texas; Barnes, V. E., proj. director: Texas Univ. Austin Bur. Econ. Geology Geol. Quad. Map, scale $1: 250,000$.

1976b, Energy resources of Texas (map): Austin, Univ. Texas, scale $1: 1,000,000$.

1977, Crystal City - Eagle Pass sheet, geologic atlas of Texas; Barnes, V. E., proj. director: Texas Univ. Austin Bur. Econ. Geology Geo1. Quad. Map, scale 1:250,000. 


\section{BIBLIOGRAPHY (continued)}

Calendar, D. L., 1957, Petrology of the Queen City Sand, Bastrop County, Texas [M.A. thesis]: Austin, Univ. Texas.

Cowart, J. B., and Osmond, J. K., 1974, Isotope techniques in ground-water hydrology: Internat. Atomic Energy Agency Symposium, 7 th, Vienna 1974, Proc., p. 131-149.

Eargle, D. H., 1968, Nomenclature of formations of the Claiborne Group, middle Eocene, Coastal Plain of Texas: U.S. Geol. Survey Bull. 1251-D, $25 \mathrm{p}$.

Eargle, D. H., Dickinson, K. A., and Davis, B. 0., 1975, South Texas uranium deposits: Am. Assoc. Petroleum Geologist Bull., v. 59, p. 766-779.

Fischer, R. P., 1974, Exploration guides to new uranium districts and belts: Econ. Geology, v. 69, p. 362-376.

Fisher, W. L., and McGowen, J. H., 1967, Depositional systems in the Wilcox Group of Texas and their relationship to occurrence of oil and gas:

Texas Univ. Austin Bur. Econ. Geology Geol. Circ. 67-4, 20 p.

Fisher, W. L., Brown, F. E., Scott, A. J., and McGowen, J. H., 1969, Highdestructive delta systems in the Gulf Coast basin, in Delta systems in the exploration for oil and gas: Texas Univ. Austin Bur. Econ. Geology, p. 35-37.

Fisher, W. L., Proctor; C.: V., Galloway, W. E., and Nagle, J. S., 1970, Depositional systems in the Jackson Group of Texas: Gulf Coast Assoc. Geol. Socs. Trans., v. 20, p. 234-260 (reprinted as Texas Univ. Austin Bur. Econ. Geology Geol. Circ. 70-4).

Folk, R. L., Hayes, M. 0., and Brown, T. E., 1961, Tertiary bentonites in central Texas, and road log - Austin to Gonzales, in Field excursion, central Texas: Texas Univ. Austin Bur. Econ. Geol. Guidebook 3, p. 5-18.

Follett, C. R., 1970, Ground-water resources of Bastrop County, Texas: Texas Water Devel. Board Rept. 109, 138 p.

Grutt, E. W., Jr., 1972, Prospecting criteria for sandstone-type uranium deposits, in Bowie, S.H.U., Davis, Michael, and Ostle, Dennis, eds., Methods of prospecting for uranium minerals: London, Inst. Mining and Metallurgy, p. 47-78.

Guevara, E. H., and Garcia, R., 1972, Depositional systems and oil-gas reservoirs in the Queen City Formation (Eocene), Texas: Texas Univ. Austin Bur. Econ. Geology Geol. Circ. 72-4, 22 p.

Guyton, W. F., and Associates, 1972, Ground-water conditions in Anderson, Cherokee, Freestone, and Henderson Counties, Texas: Texas Water Devel. Board Rept. 150, 250 p. 
Jones, P. H., Stevens, P. R., Wesselman, J. B., and Wallace, R. H., Jr., 1976, Regional appraisal of the Wilcox Group in Texas for subsurface storage of fluid wastes, pt. 1 - Geology: U.S. Geol. Survey Open-File Rept. 76-394, $107 \mathrm{p}$.

Kaiser, W. R., 1974, Texas lignite: Near-surface and deep basin resources: Texas Univ. Austin Bur. Econ. Geology Rept. Inv. 79, 70 p.

Lowman, S: W., 1949, Sedimentary facies in Gulf coast: Aim. Assoc. Petroleum Geologists Bull., v. 33, p. 1939-1997.

Meltzer, L. H., and Boyd, D. R., chairmen, 1972, Tectonic map of Gulf Coast region, U.S.A.: Jointly published by Gulf Coast Assoc. Geol. Socs. and Am. Assoc. Petroleum Geologists, scale 1:1,000,000.

Murray, G. E., 1961, Geology of the Atlantic and Gulf Coastal province of North America: New York, Harper \& Row Pubs., Geoscience Ser:., 691 p.

Payne, J. N., 1968, Hydrologic significance of the lithofacies of the Sparta Sand in Arkansas, Louisiana, Mississippi, and Texas: U.S. Geol. Survey Prof. Paper 569-C, 17 p., 10 pls.

1972, Hydrologic significance of 1ithofacies of the Cane River Formation or equivalents of Arkansas, Louisiana, Mississippi, and Texas: U.S. Geol. Survey Prof. Paper 569-C, 17 p., 16 pls.

1975, Geohydrologic significance of lithofacies of the Carrizo Sand of Arkansas, Louisiana, and Texas and the Meridian sand of Mississippi: U.S. Geol. Survey Prof. Paper 569-D, 11 p., 9 pls.

Southern Interstate Nuclear Board, 1969, Uranium in the southern United States: U.S. Atomic Energy Comm. WASH-1128, 230 p., 3 pls.

Williams, Howel, Turner, F. J., and Gilbert, C. M., 1954, Petrography: An incroduction to the sludy of rocks in thin sections: San Francisco, W. H. Freeman and Co., 406 p.

Young, K. P., 1962, Mesozoic history, Llano region, in Geology of the Guif Coast and Central Texas and guidebook of excursions: Houston Geol. suc., p. 98-106. 
APPENDIX A

TOTAL AND EXTRACTABLE $U_{3} \mathrm{O}_{B}$ ANALYTICAL DATA FROM SURFACE SAMPLES 
APPENDIX A. TOTAL AND EXTRACTABLE $\mathrm{U}_{3} \mathrm{O}_{8}$ ANALYTICAL DATA FROM SURFACE SAMPLES

Sample no.

\begin{tabular}{|c|c|c|c|c|c|}
\hline $\begin{array}{l}\text { Field } \\
(\mathrm{P} 1.2)\end{array}$ & Lab & $\begin{array}{c}\text { Stratigraphic } \\
\text { unit }\end{array}$ & County. & $\begin{array}{c}\text { Total } \mathrm{U}_{3} \mathrm{O}_{8} \\
(\mathrm{ppm})\end{array}$ & $\begin{array}{l}\text { Extractable } \\
\mathrm{U}_{3} \mathrm{O}_{8} \text { (ppm) }\end{array}$ \\
\hline MAC 027 & 20502 & Carrizo & Bastrop & 3 & $1 *$ \\
\hline 028 & 20503 & Carrizo & Bastrop & 1 & $1 *$ \\
\hline 029 & 20504 & Reklaw & Bastrop & 1 & $I *$ \\
\hline 030 & 20505 & Queen City & Bastrop & 6 & $2 *$ \\
\hline 031 & 20506 & Queen City & Bastrop & 4 & $1 *$ \\
\hline 033 & 20508 & E1 Pico & Frio & 3 & $3 * *$ \\
\hline 034 & 20509 & El Pico & Frio & 2 & --- \\
\hline 035 & 20510 & El Pico & Dimmit & 3 & $2 * *$ \\
\hline 036 & 20511 & Bigford & Dimmit & 2 & ---- \\
\hline 037 & 20512 & Laredo & Webb & 3 & --- \\
\hline 038 & 20513 & Laredo & Webb & 2 & ---- \\
\hline 039 & 20514 & Laredo & LaSalle & 2 & $-\cdots$ \\
\hline 040 & 20515 & E1 Pico & Dimmit & 5 & $3 * *$ \\
\hline 041 & 20516 & Laredo & Dimmit & 1 & ---- \\
\hline 042 & 20517 & Laredo & Frio & 1 & ---- \\
\hline 043 & 20518 & Carrizo & Frio & 1 & --- \\
\hline 044 & 20519 & Carrizo & Zavala & 2 & ---- \\
\hline 045 & 20520 & $\begin{array}{l}\text { Indio (Wilcox } \\
\text { Group) }\end{array}$ & Uvalde & 1 & ---- \\
\hline 046 & 20521 & Wilcox Group & Medina & 2 & ---- \\
\hline 047 & 20522 & Wilcox Croup & Medina & 1 & --- \\
\hline 048 & 20523 & Wilcox Group & Medina & 2 & --- \\
\hline 049 & 20524 & Carrizo & Medina & 1 & --- \\
\hline 050 & 20525 & Carrizo & Medina & 2 & $-\infty$ \\
\hline 176 & 20526 & Rek.1.Atat & Erio & 1 & $==-=-$ \\
\hline 177 & 20527 & Queen City & Frio & 1 & --- \\
\hline 178 & 20528 & Carrizo & Bexar & 4 & $2 * *$ \\
\hline 179 & 20529 & Carrizo & Bexar & 3 & $1 * *$ \\
\hline 180 & 20530 & Cook Mtn. & Atascosa & 3 & $3 * *$ \\
\hline 181 & 20531 & Queen City & Wilson & 3 & $1 * *$ \\
\hline 182 & 20532 & Reklaw & Wilson & 4 & $2 * *$ \\
\hline 183 & 21.888 & Carrizo & Bastrop & 2 & ---- \\
\hline 184 & 21889 & Weches & Juee & 2 & ---- \\
\hline 185 & 21890 & $\begin{array}{l}\text { Simsboro } \\
\text { (Wilcox) }\end{array}$ & Limestone & 17 & $10 * *$ \\
\hline 186 & 21891 & $\begin{array}{l}\text { Simsboro } \\
\text { (Wilcox) }\end{array}$ & Limes tone & 1. & --- \\
\hline 187 & 21892 & Carrizo & Leon & 1 & --- \\
\hline 188 & 21893 & Queen City & Leon & 1 & ---- \\
\hline 189 & 21894 & Sparta & Leon & 2 & $--\infty$ \\
\hline 190 & 21895 & Sparta & Leon & 1 & --- \\
\hline 191 & 21896 & Wilcox Group & Shelby & 3 & --- \\
\hline 192 & 21897 & Wilcox Group & Shelby & 2 & --- \\
\hline 193 & 21898 & Wilcox Group & Shelby & 2 & --- \\
\hline 194 & 21899 & Carrizo & Rusk & 1 & ---- \\
\hline 19.5 & 2.1 .900 & Queen City & Upshur & 25 & $24 * *$ \\
\hline
\end{tabular}


APPENDIX A (continued)

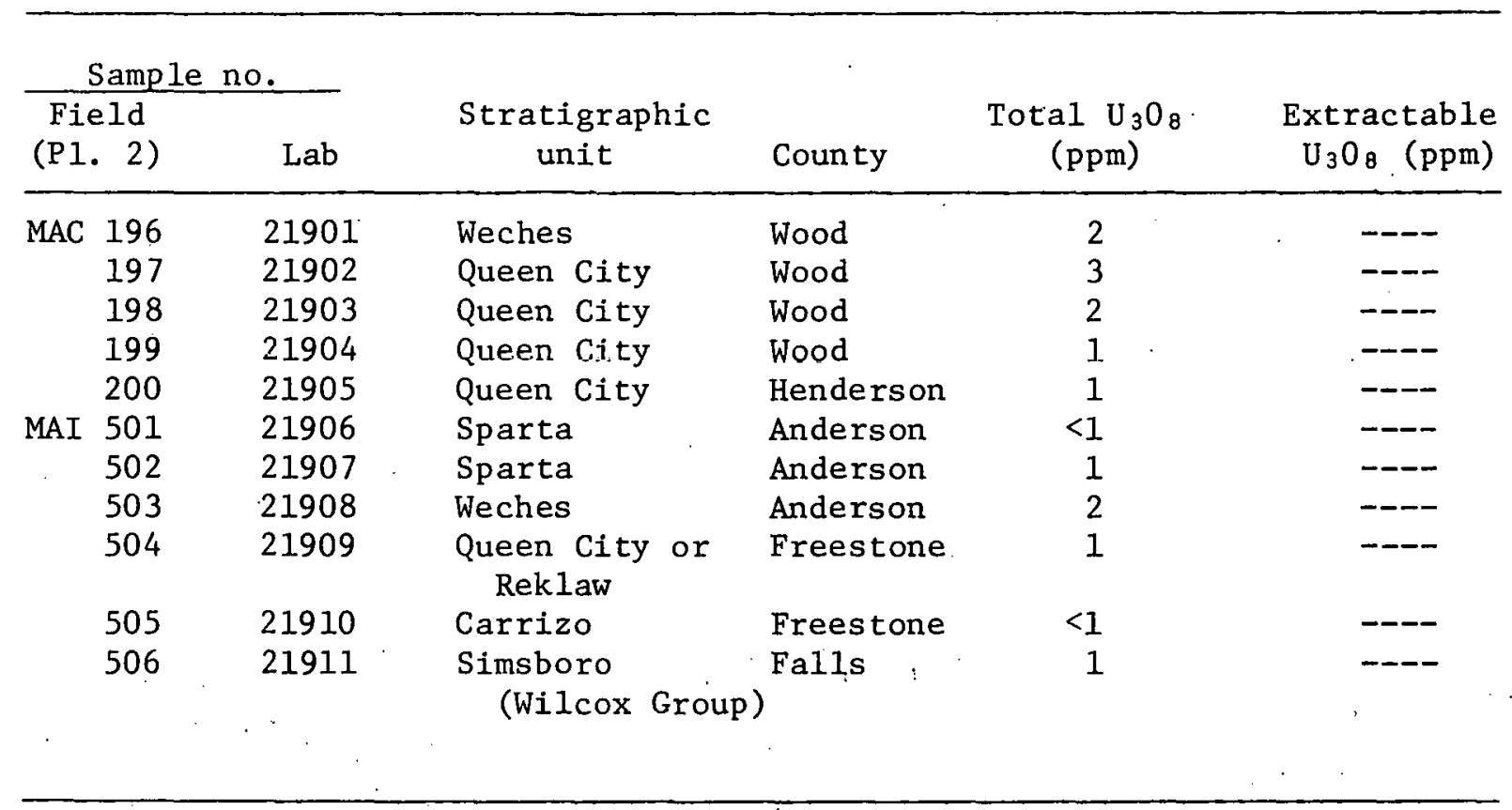

--- = Extractable $\mathrm{U}_{3} \mathrm{O}_{8} \cdot$ not determined

* = Cold extractable

$* *=$ Extractable in hot $4 \mathrm{~N} \mathrm{HNO}_{3}$

NOTES:

1. Sample MAI-504 (21909) was used in computing averages of both Queen City and Reklaw Formations for Figure 2.

2. Resampling of MAC-185 (21890) and MAC-195 (21900) showed no $\mathrm{U}_{3} 0_{8}$ anomaly. Values shown in this appendix may be contaminated, MAC-185 by pesticides and MAC-195 by hydrocarbons. 
APPENDIX B

PATHF INDER ELEMENT ANALYSES

OF ANOMALOUS SAMPLES 
APPENDIX B. PATHFIIJDER ELEMENT ANALYSES OF ANOMALOUS SAMPLES

\begin{tabular}{|c|c|c|c|c|c|c|c|c|c|c|}
\hline$\frac{\text { Sample }}{\text { Field }}$ & no. & $\begin{array}{l}\text { Stratigraphic } \\
. \quad \text { üit }\end{array}$ & County & $\begin{array}{c}\text { Total } \mathrm{U}_{3} \mathrm{O}_{8} \\
(\mathrm{ppm})\end{array}$ & $\begin{array}{c}\text { Extractable } \mathrm{U}_{3} \mathrm{O}_{8} \\
(\mathrm{ppm})\end{array}$ & $\begin{array}{l}\mathrm{V}_{2} \mathrm{O}_{5} \\
(\mathrm{ppm})\end{array}$ & $\begin{array}{c}\mathrm{Se} \\
\text { (ṕpm) }\end{array}$ & $\begin{array}{c}\text { Mo } \\
\text { (ppm) }\end{array}$ & $\begin{array}{c}\text { As } \\
\text { (ppm) }\end{array}$ & $\begin{array}{c}\mathrm{Pb} \\
(\mathrm{ppm})\end{array}$ \\
\hline MAC 185 & 21890 & Simsboro & Limes tone & 17 & 10 & 123 & $i$ & $i$ & 248 & 46 \\
\hline MAC 195 & 21900 & Queen City & Üpshur & 25 & 24 & 89 & 1 & 1 & 0 & 79 \\
\hline
\end{tabular}




\section{APPENDIX C \\ GAMMA-RAY LOGS \\ WITH ANOMALOUS RADIOACTIVITY \\ FROM CLAIBORNE OR WILCOX STRATA}


APPENDIX C. GAMMA-RAY LOGS W-TH ANOMALOUS RADIOACTIVITY (AT LEAST 2X BACKGROUND) FROM CLAIBORNE OR WILCOX STRATA

\begin{tabular}{|c|c|c|c|c|c|c|}
\hline $\begin{array}{c}\text { Location } \\
\text { no. (P1. 1) }\end{array}$ & We11 name & Field & County & $\log _{(\mathrm{ft})}^{\operatorname{depth}}$ & Lithology & $\begin{array}{c}\text { Stratigraphic } \\
\text { interval }\end{array}$ \\
\hline 1 & Chevron, \#1 Mary Wițhers & Nevis & Anderson & $2,842-2,863$ & shale & Wx? \\
\hline 2 & J.E. Anderson $\#_{1} 1$ Leary & Salt Flat & Caldwe11 & $770-785$ & - & $W x$ \\
\hline 3 & Colorado Oil 非1 Cora Malone & Salt Flat & Caldwell & $\begin{array}{l}160-165 \\
168-180 \\
960-970\end{array}$ & $\begin{array}{l}\text { sand } \\
\text { sand } \\
\text { shale }\end{array}$ & $\begin{array}{l}W x \\
W x \\
W x\end{array}$ \\
\hline 4 & Colorado Oil \#15 Merriweather & Salt Flat & Caldwell & $705-710$ & shale & $W x$ \\
\hline 5 & Ellang Oil 非 Dunlap & Dunlap & Caldwe 11 & $200-225$ & sand & $\mathrm{C}$ or $\mathrm{Wx}$ \\
\hline 6 & F.C. Lattner 非 7 W.T. Davis & Spiller & Caldwel1 & $\begin{array}{l}565-572 \\
625-635\end{array}$ & $\begin{array}{l}\text { sand } \\
\text { șand }\end{array}$ & $\begin{array}{l}\text { Wx } \\
W x\end{array}$ \\
\hline 7 & F.C. Lattner \#7 Garland Harris & Spiller & Caldwell & $\begin{array}{l}438-442 \\
495-505\end{array}$ & $\begin{array}{l}\text { sand } \\
\text { sand }\end{array}$ & $\begin{array}{l}\text { Wx } \\
\text { Wx }\end{array}$ \\
\hline 8 & F.C. Lattner 非14 Greenwood & Spiller & Caldwell & $\begin{array}{l}495-505 \\
550-560\end{array}$ & $\begin{array}{l}\text { shale } \\
\text { sand }\end{array}$ & $\begin{array}{l}\text { Wx } \\
\text { Wx }\end{array}$ \\
\hline 9 & F.C. Lattner \#14 0'Banion & Spiller & Caldwe11 & $\begin{array}{l}506-508 \\
564-568\end{array}$ & $\begin{array}{l}\text { shale } \\
\text { shale }\end{array}$ & $\begin{array}{l}W x \\
W x\end{array}$ \\
\hline 10 & F.C. Lattner \#16 o'Banion & Spiller & Caldwell & $\begin{array}{l}540-545 \\
602-610\end{array}$ & $\begin{array}{l}\text { shale } \\
\text { shale }\end{array}$ & $\begin{array}{l}W x \\
W x\end{array}$ \\
\hline 11 & Luling 0il \#A-1 Floy Gay & Salt Flat & Caldwe1l & $495-500$ & sand & $W x$ \\
\hline 12 & Luling Oi1 非 C.F. Dye & Salt Flat & Caldwe1l & $370-380$ & - & $W x$ \\
\hline
\end{tabular}


APPENDIX C (continued)

\begin{tabular}{|c|c|c|c|c|c|c|c|}
\hline no. & $\begin{array}{l}\text { ocation } \\
\text { (P1. 1) }\end{array}$ & Well name & Field & County & $\underset{(f t)}{\log \operatorname{dep}^{t h}}$ & Lithology & $\begin{array}{c}\text { Stratigraphic } \\
\text { interval }\end{array}$ \\
\hline & 13 & Luling Oil \#9 Tiller & Salt Flat & Caldwe 11 & $510-520$ & shale & Wx \\
\hline & 14 & Luling 0i1 \#7 Tiller & Salt Flat & Caldwel1 & $280-285$ & sand & $\mathrm{Wx}$ \\
\hline & 15 & Luling Oil \#10 Tiller & Salt Flat & Caldwe 11 & $540-550$ & sand & Wx \\
\hline & 16 & Magnolia \#1 Tabor & Luling & Caldwe11 & $930-960$ & shale & Wx \\
\hline & 17 & Stan-Band \#A-1 A.B. Fowler & $\begin{array}{l}\text { Wildcat } \\
\text { well }\end{array}$ & Caldwell & $350-365$ & sand & $W x$ \\
\hline & 18 & Frank Gravis 非 Frank Gravis & $\begin{array}{l}\text { Wildcat } \\
\text { we11 }\end{array}$ & Guadalupe & $230-250$ & - & Wx? \\
\hline & 19 & Long \& Johnson \#1 Masterson & LaVernia & Guadalupe & $245-255$ & - & $\underline{W x}$ \\
\hline & 20 & Long \& Johnson $¥ 2$ Masterson & LaVernia & Guadalupe & $244--254$ & - & W $x$ \\
\hline & 21 & D.0. Wade 非 Dinner & LaVernia & Guadalupe & $282-287$ & - & $\underline{\mathrm{Wx}}$ \\
\hline & 2.2 & Shel1 \#1 D.J. Hamilton & $\begin{array}{l}\text { Wildcat } \\
\text { well }\end{array}$ & Robertson & $\begin{array}{l}1,680-1,760 \\
1,810-1,820\end{array}$ & $\overline{-}$ & $\begin{array}{l}\text { Wx } \\
\text { Wx }\end{array}$ \\
\hline & 23 & $\begin{array}{l}\text { Union 0il \#412 Carroll } \\
\text { Waterford }\end{array}$ & Van & Titus & $2,112-2,115$ & - & Wx? \\
\hline & 24 & Frank Cambel1 非-1 Kirkpatrick & Tal Vez & Webb & $1,724-1,728$ & sand & $\mathrm{C} ?$ \\
\hline & 25 & Keg Dil 非6 C.E. Benavides & $\begin{array}{l}\text { Carolina } \\
\text { Tex-W. }\end{array}$ & Webb & $\begin{array}{l}1,180-1,190 \\
2,600-2,607\end{array}$ & $\begin{array}{l}\text { sand } \\
\text { shale }\end{array}$ & $\begin{array}{l}\mathrm{C} \\
\mathrm{C}\end{array}$ \\
\hline
\end{tabular}


APPENDIX C (continued)

\begin{tabular}{|c|c|c|c|c|c|c|}
\hline $\begin{array}{c}\text { Location } \\
\text { no. }(\mathrm{P} 1.1)\end{array}$ & We11 name & Field & County & $\begin{array}{l}\text { Log depth } \\
\text { (ft) }\end{array}$ & Lithology & $\begin{array}{c}\text { Stratigraphic } \\
\text { interval }\end{array}$ \\
\hline 27 & $\begin{array}{l}\text { Tower Prod. Co. \#4 Victoria } \\
\text { Nal. Bank }\end{array}$ & Kaye & Wilson & $1,592-1,600$ & - & Wx \\
\hline 28 & Wise Drlg. 非 4 Higgins & Híggins & Wilson & $\begin{array}{c}240-242 \\
250-260 \\
420-440 \\
670-710 \\
760-1,030 \\
1,170-1,230 \\
1,580-1,595 \\
2,010-2,020 \\
2,300-2,310 \\
2,410-2,420 \\
2,550-2,560 \\
2,630-2,650 \\
2,780-2,800\end{array}$ & $\begin{array}{l}\text { shale } \\
\text { shale } \\
\text { shale } \\
\text { shale } \\
\text { shale } \\
\text { shale } \\
\text { shale } \\
\text { shale } \\
\text { sand } \\
\text { sand } \\
\text { sand } \\
\text { sand } \\
\text { shale }\end{array}$ & $\begin{array}{l}C \\
C \\
C \\
C \\
C \\
C \\
W x \\
W x \\
W x \\
W x \\
W x \\
W x \\
W x\end{array}$ \\
\hline
\end{tabular}

Wx - Wilcox, anomaly determined from test well log.

Wx - Wilcox, anomaly determined from structure map.

C - Claiborne, anomaly determined from structure map.

C? - Claiborne(?) (Yegua?), anomaly determined from structure map. 


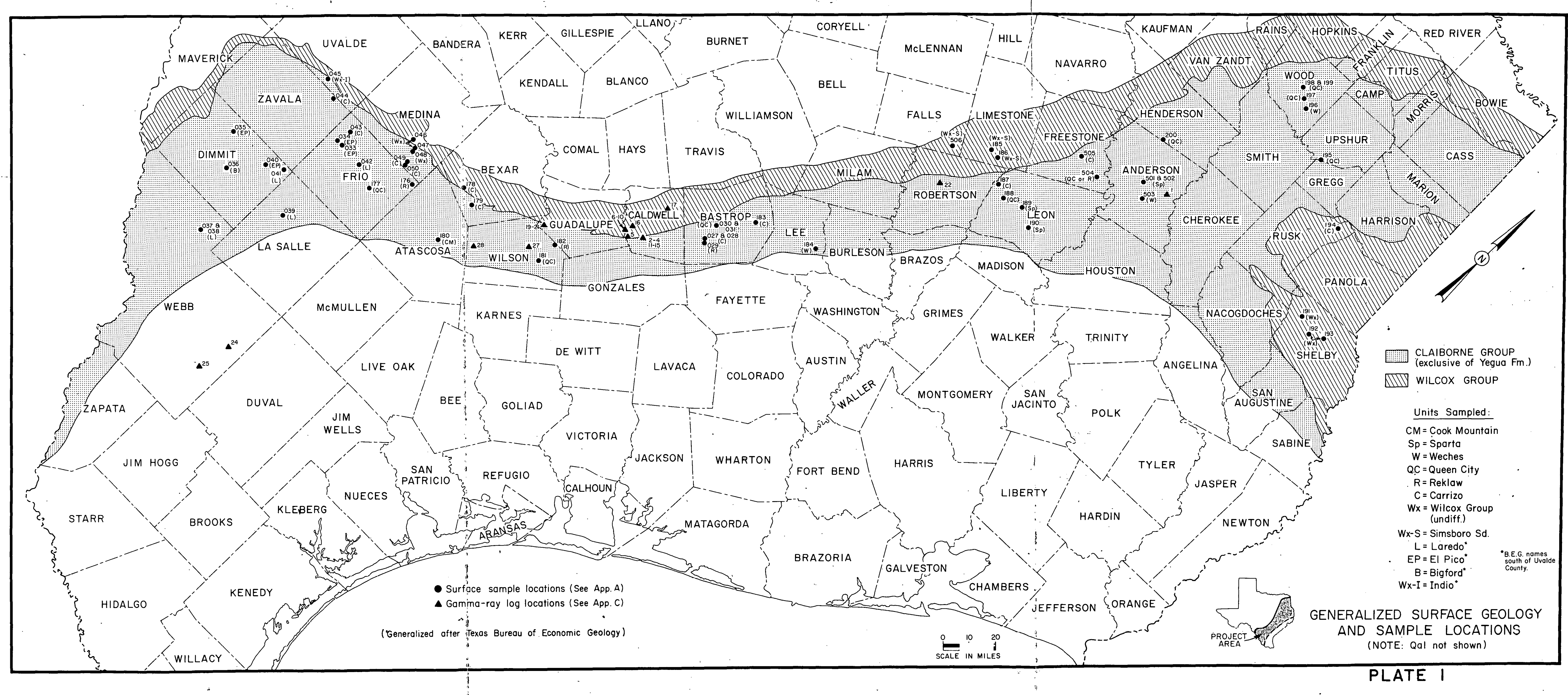




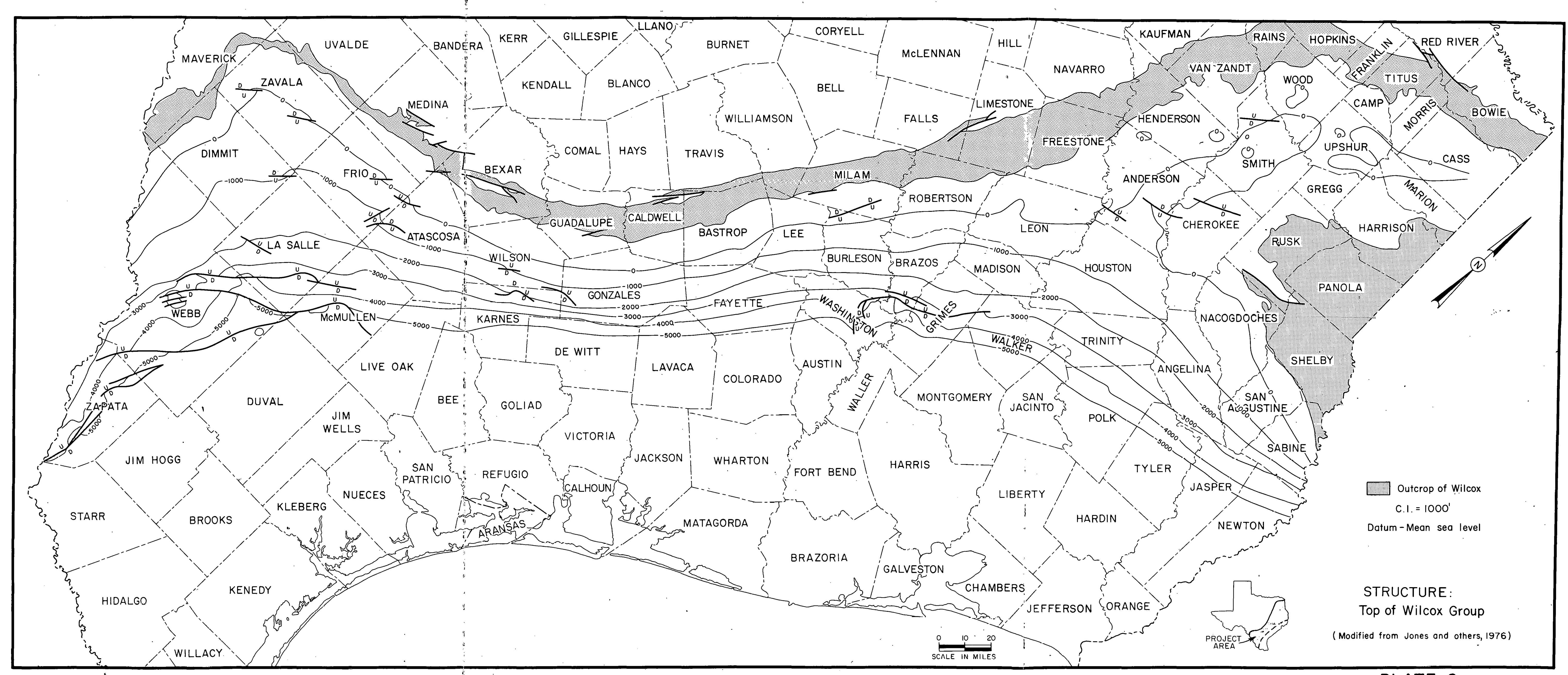




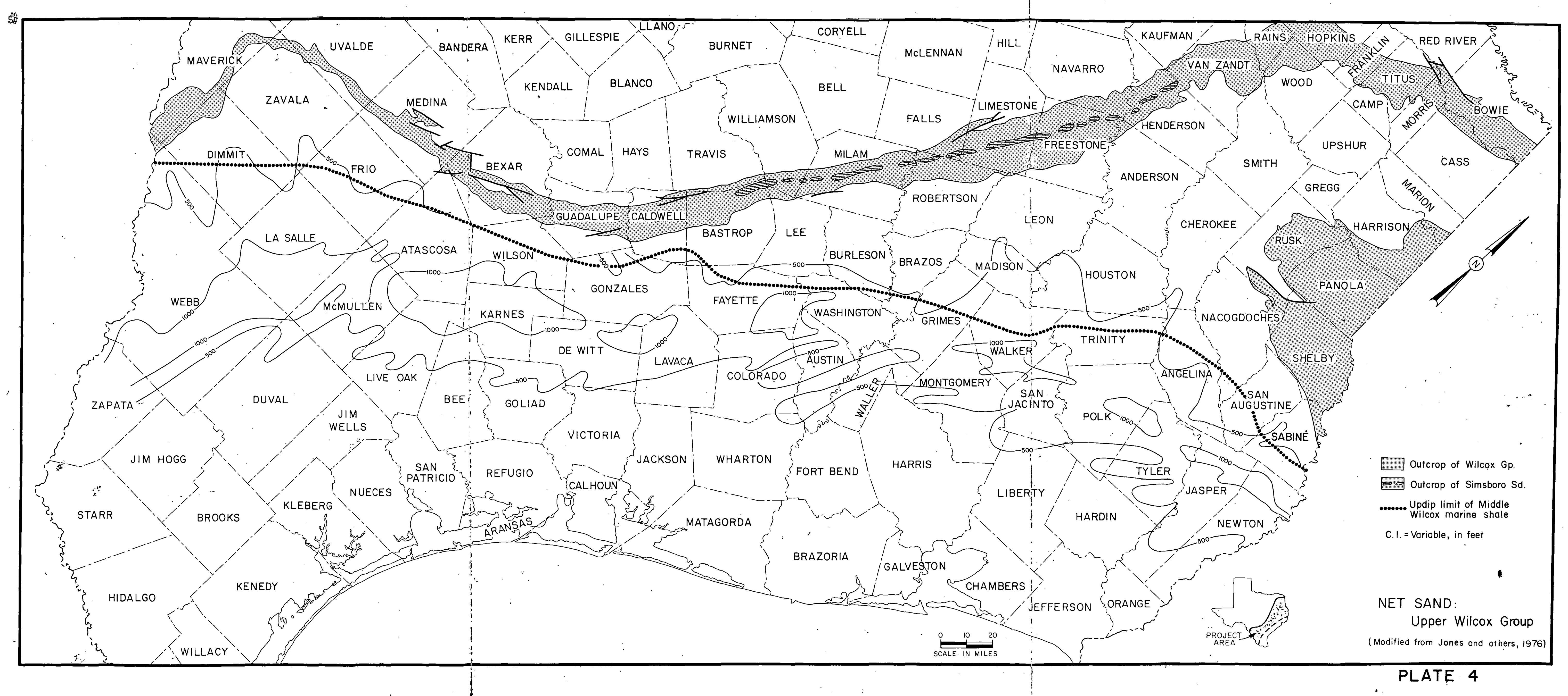




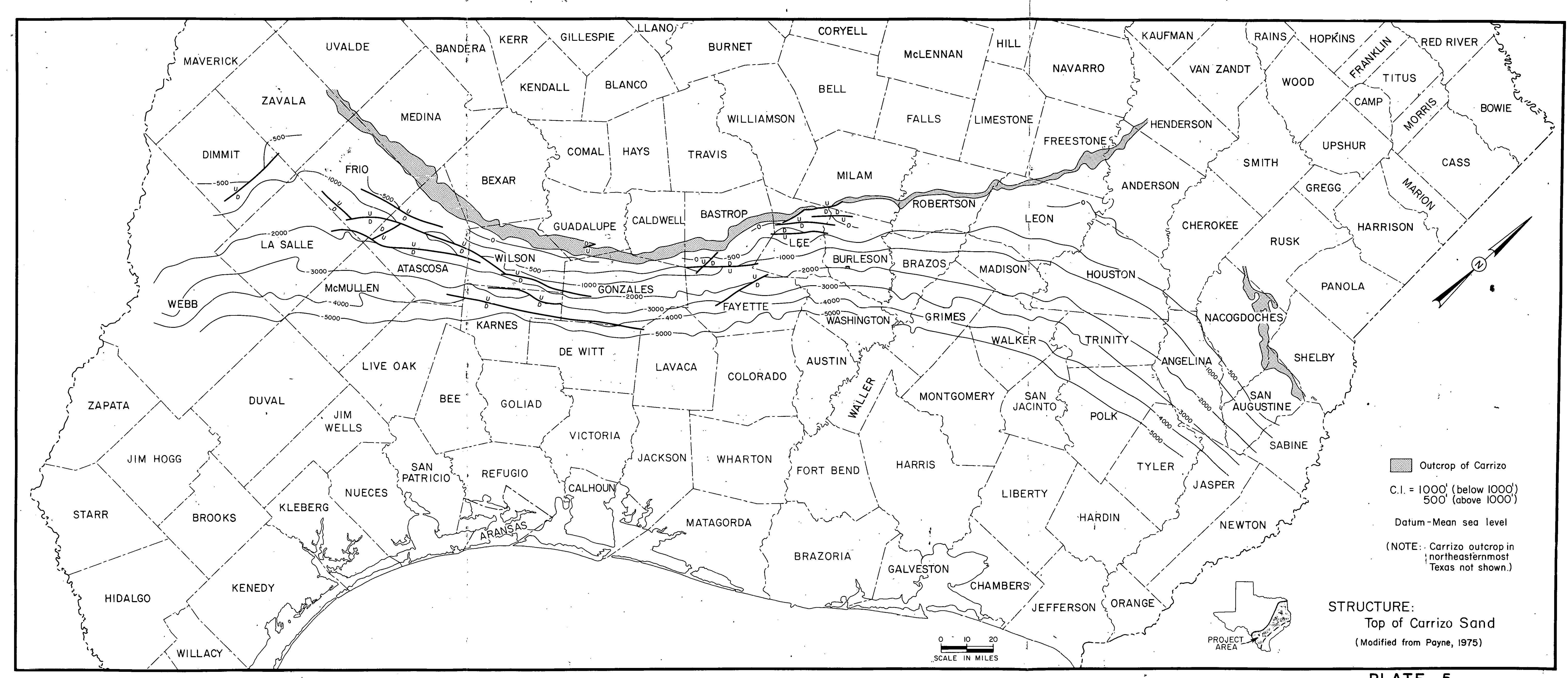

PLATE 5 


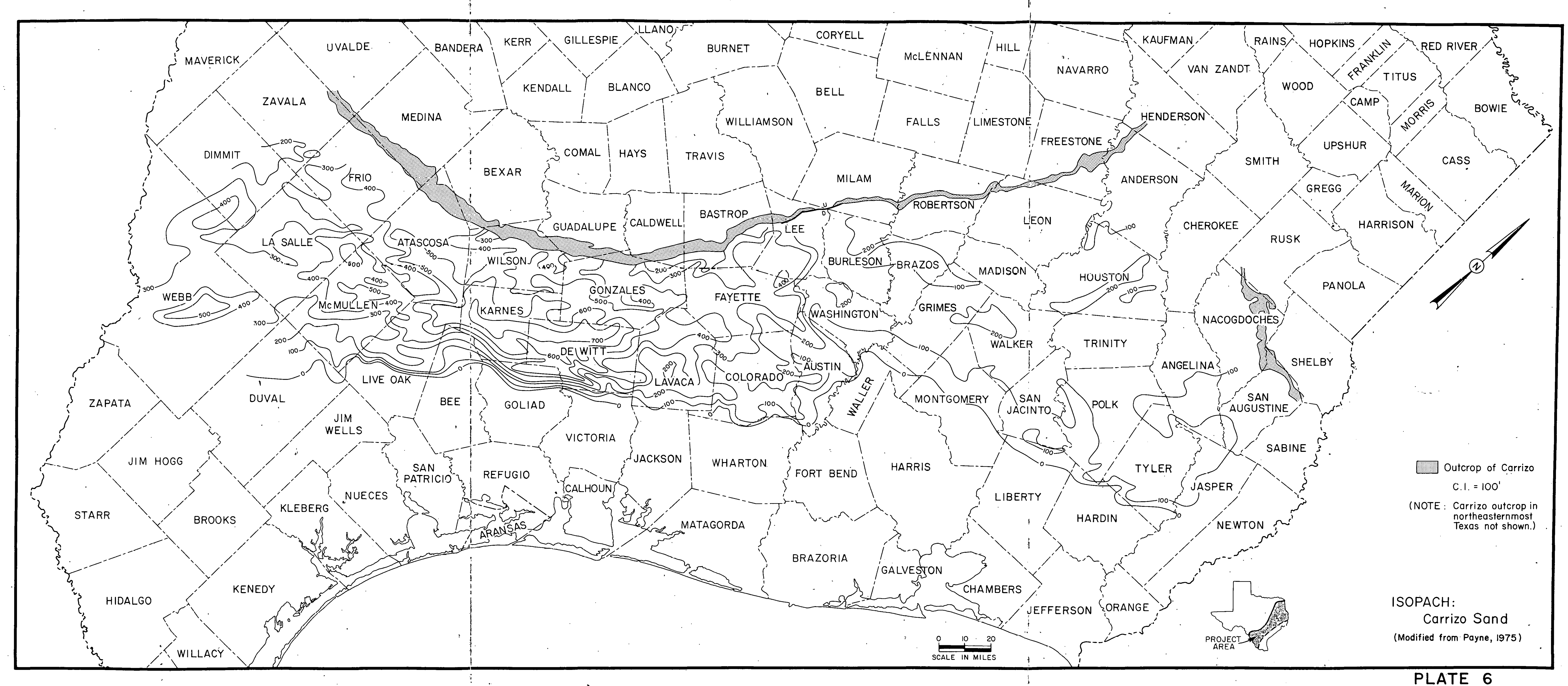




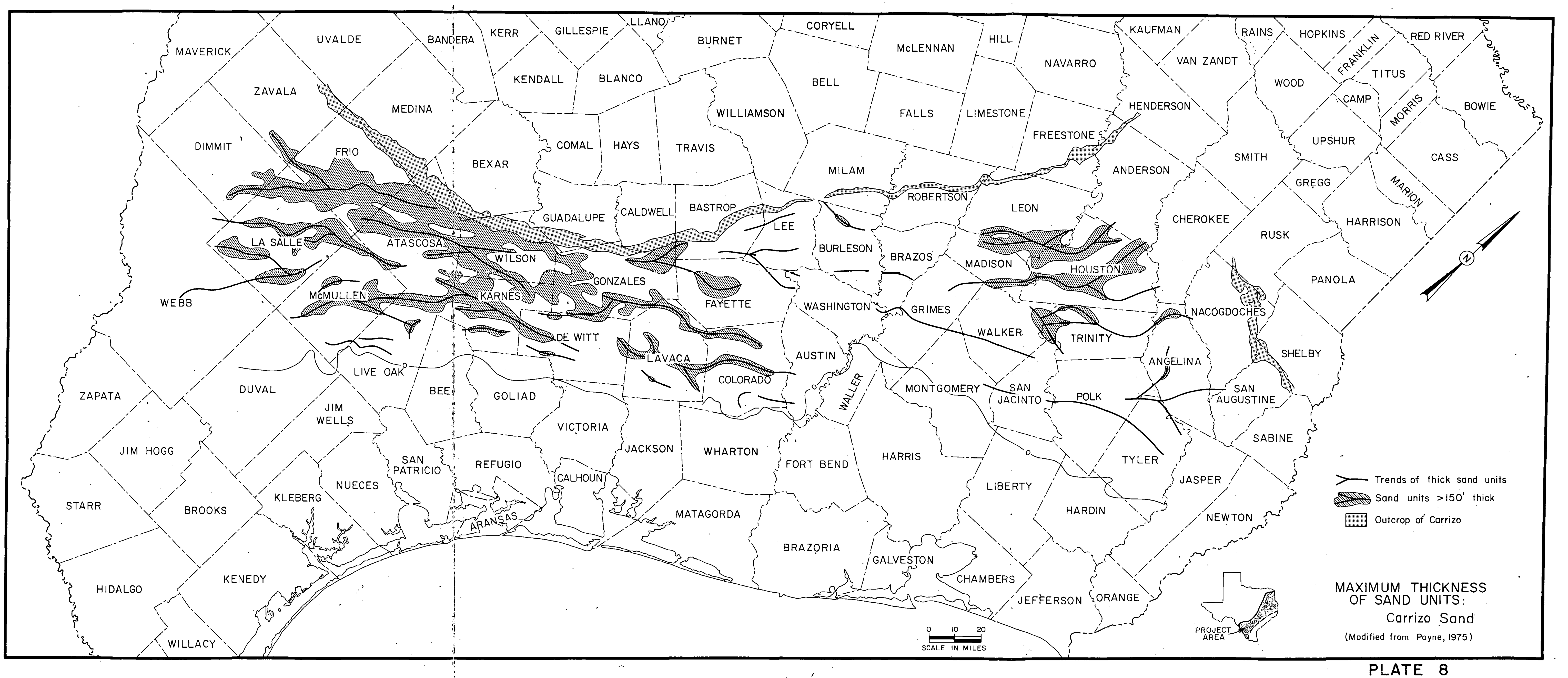




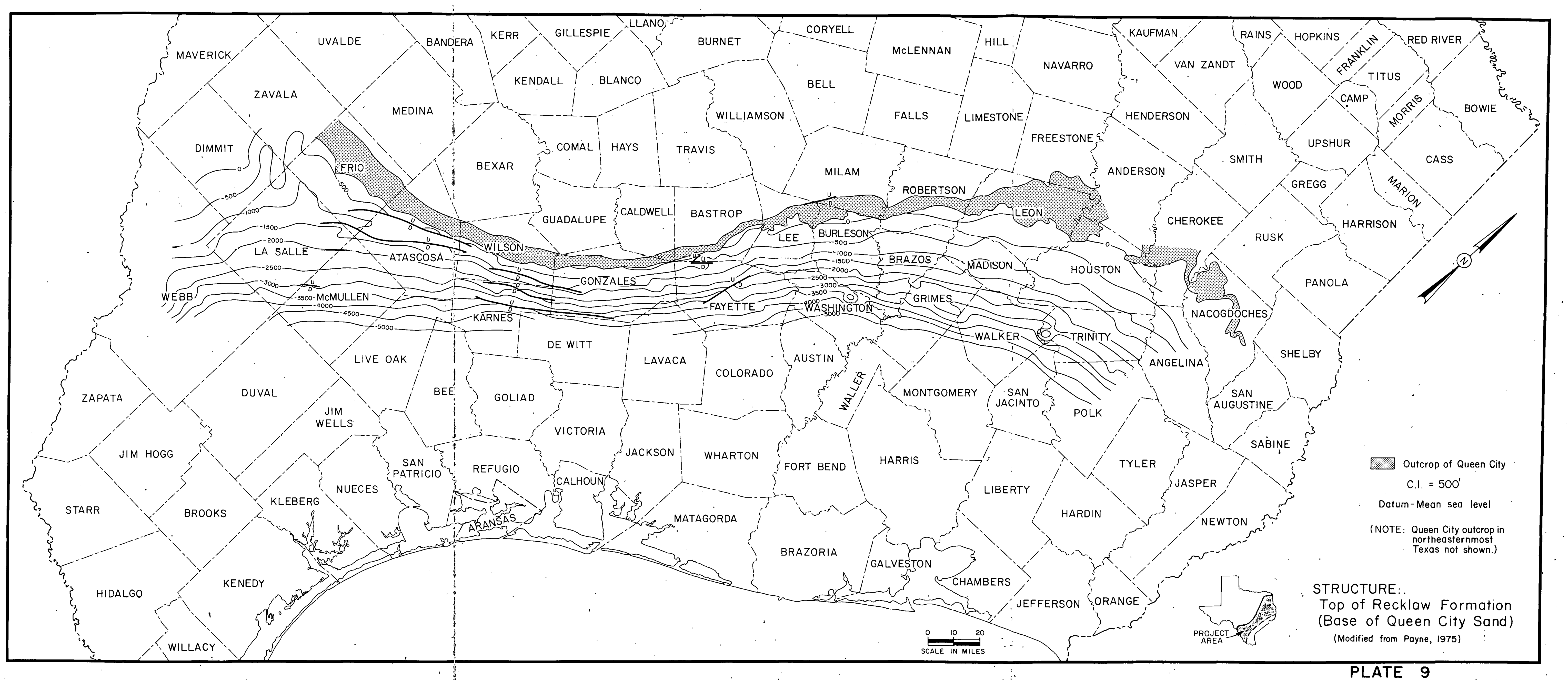




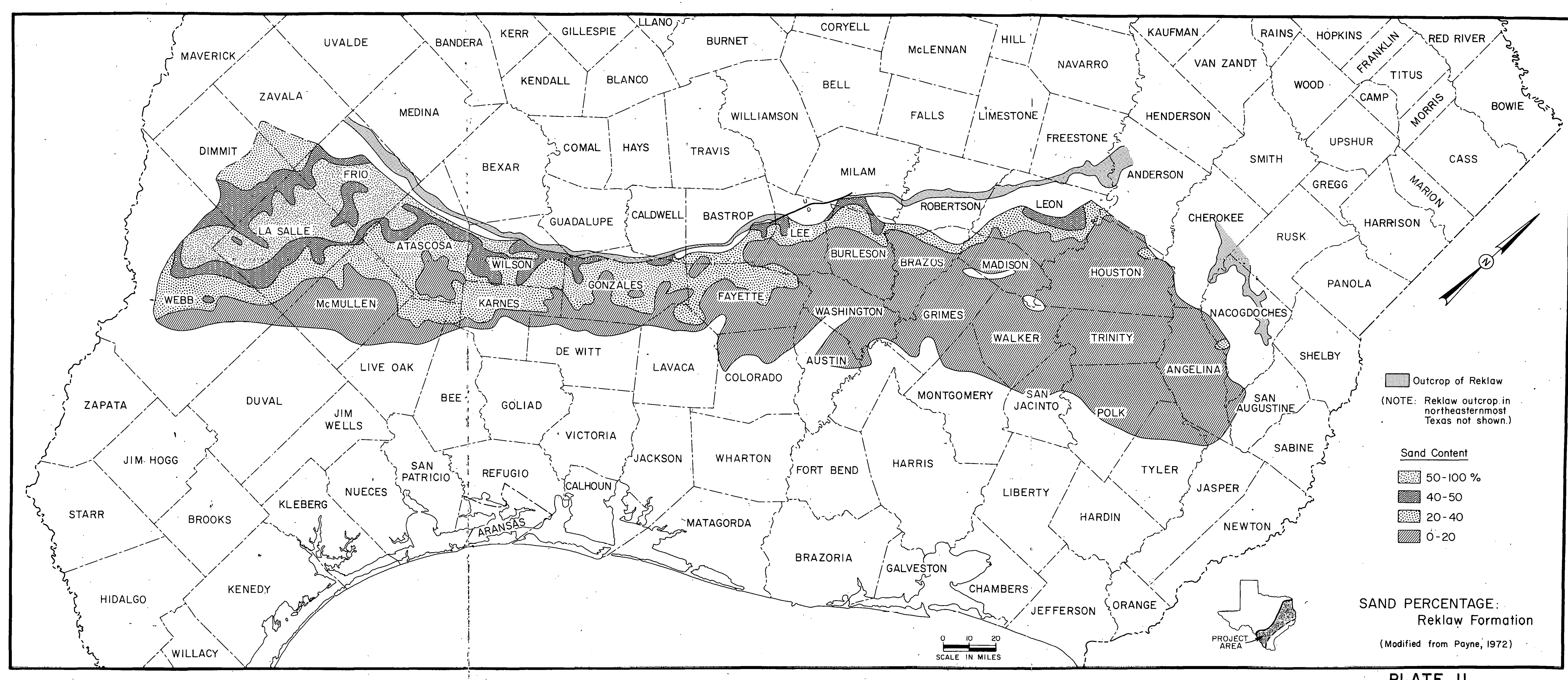




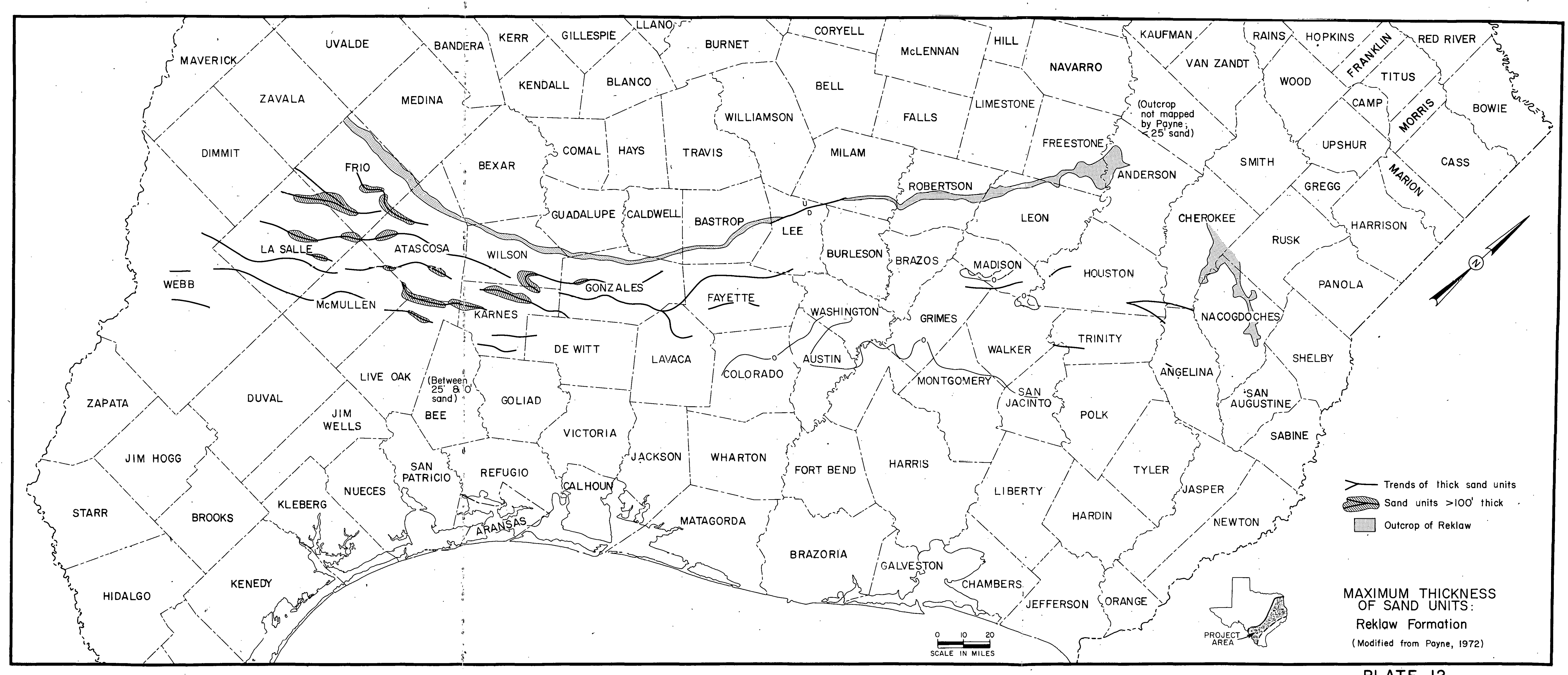

PLATE 12 


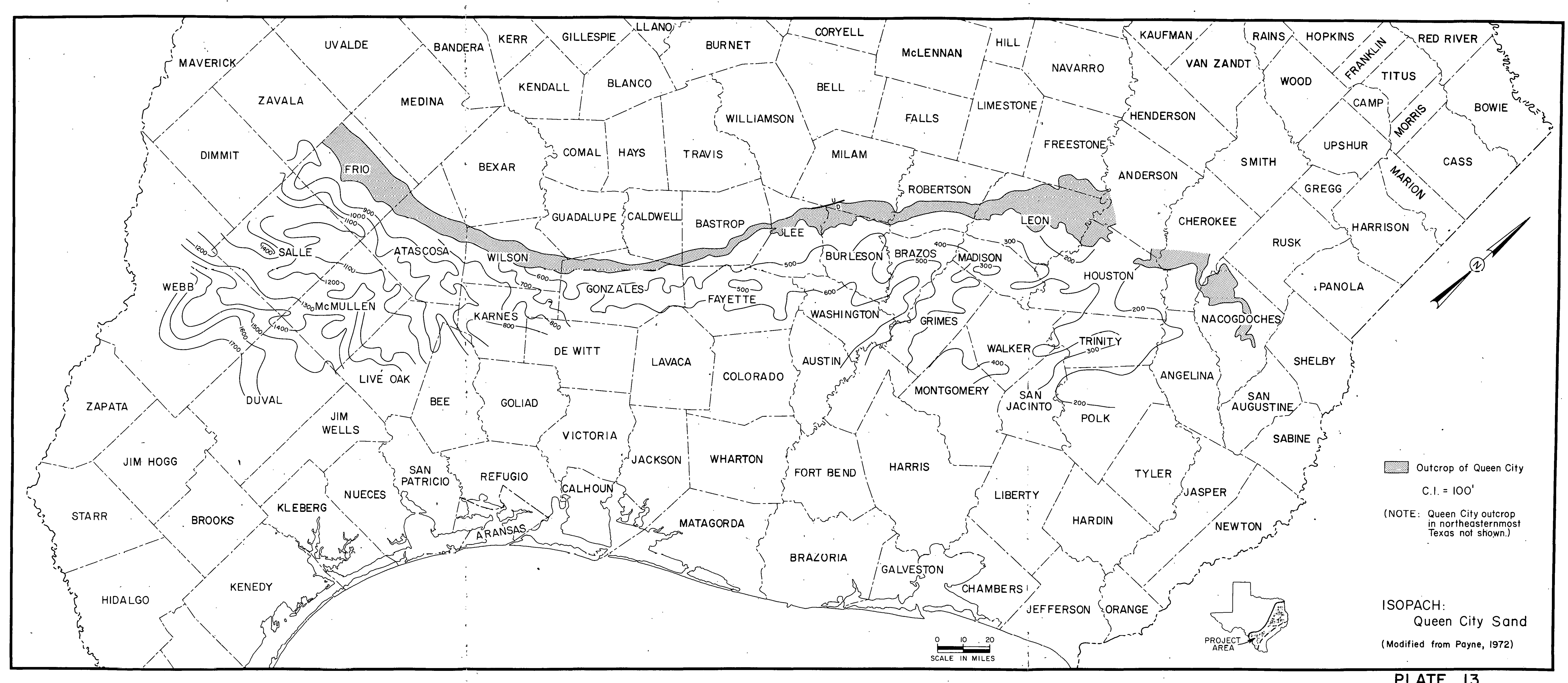

PLATE 13 


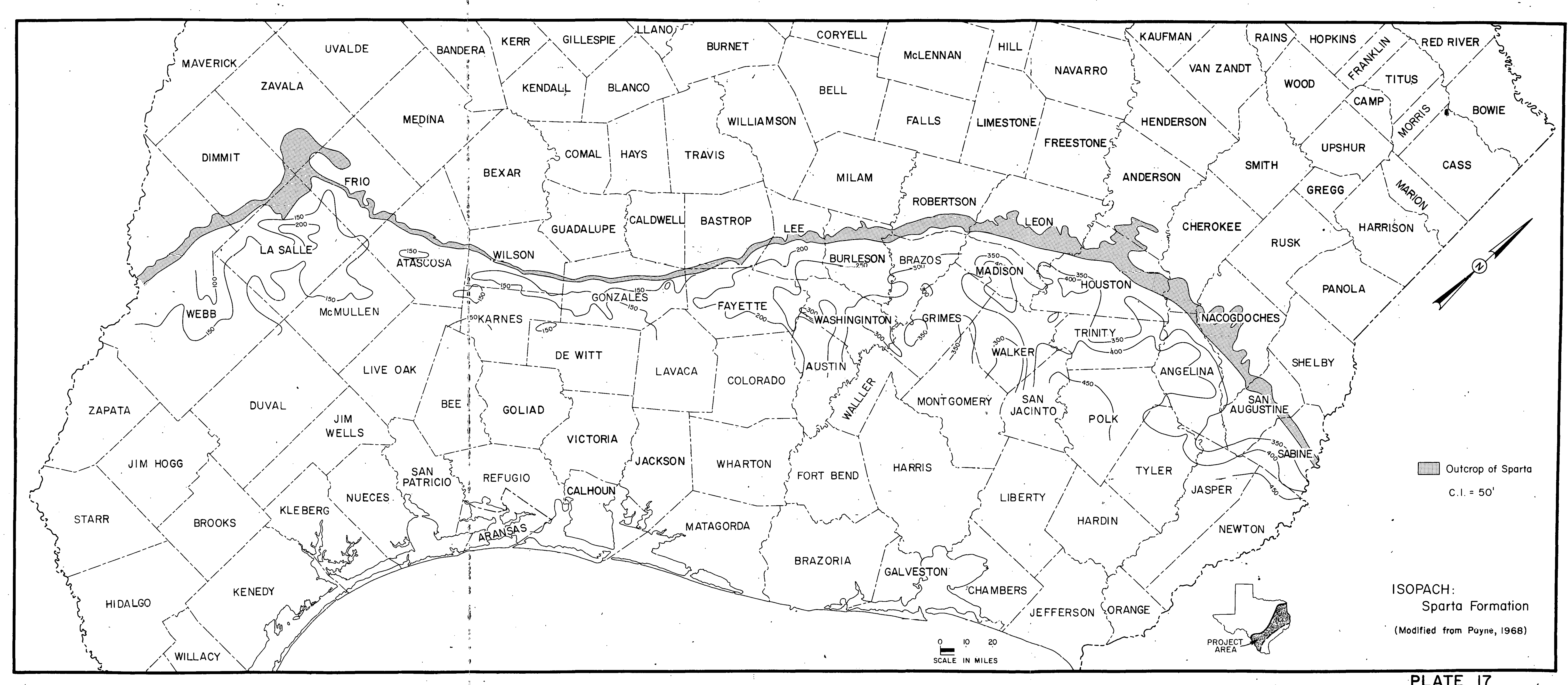

PLATE 17 


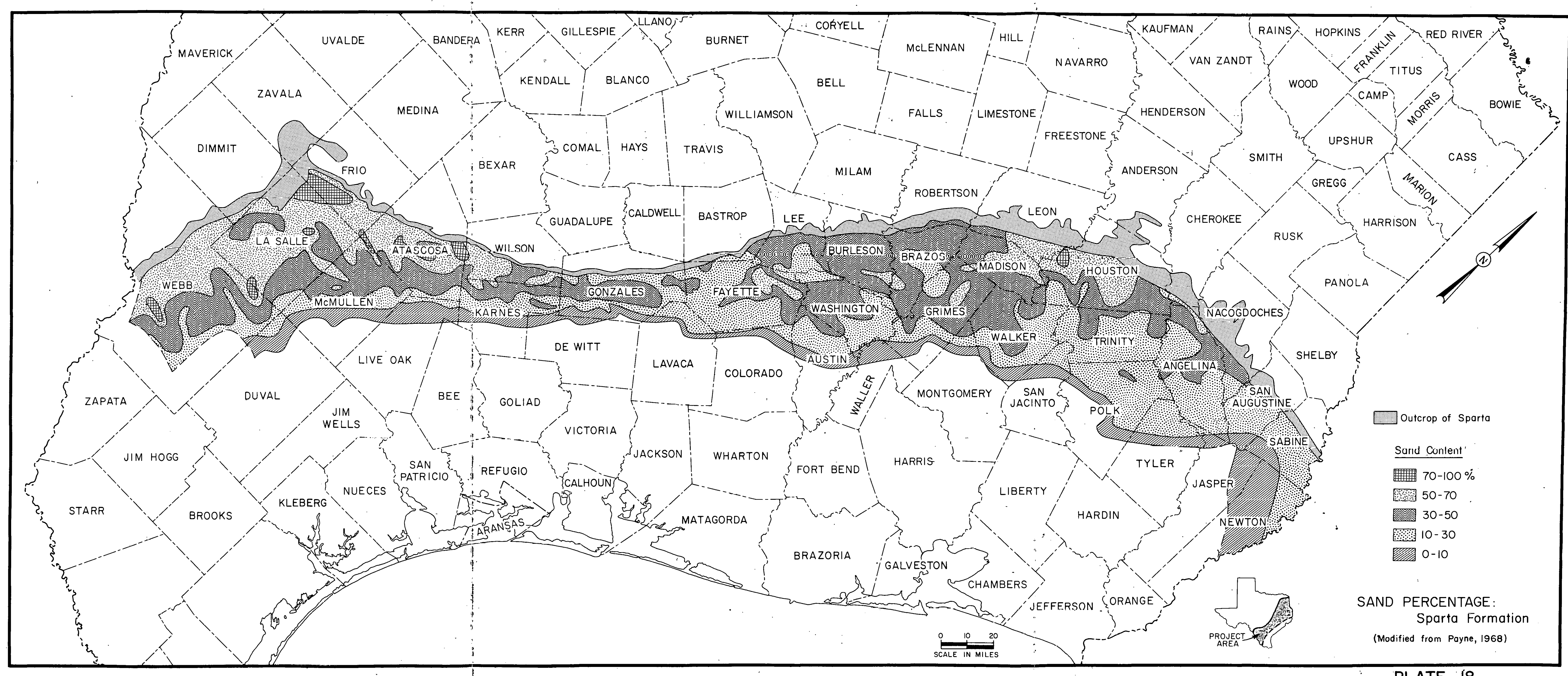

PLATE 18 


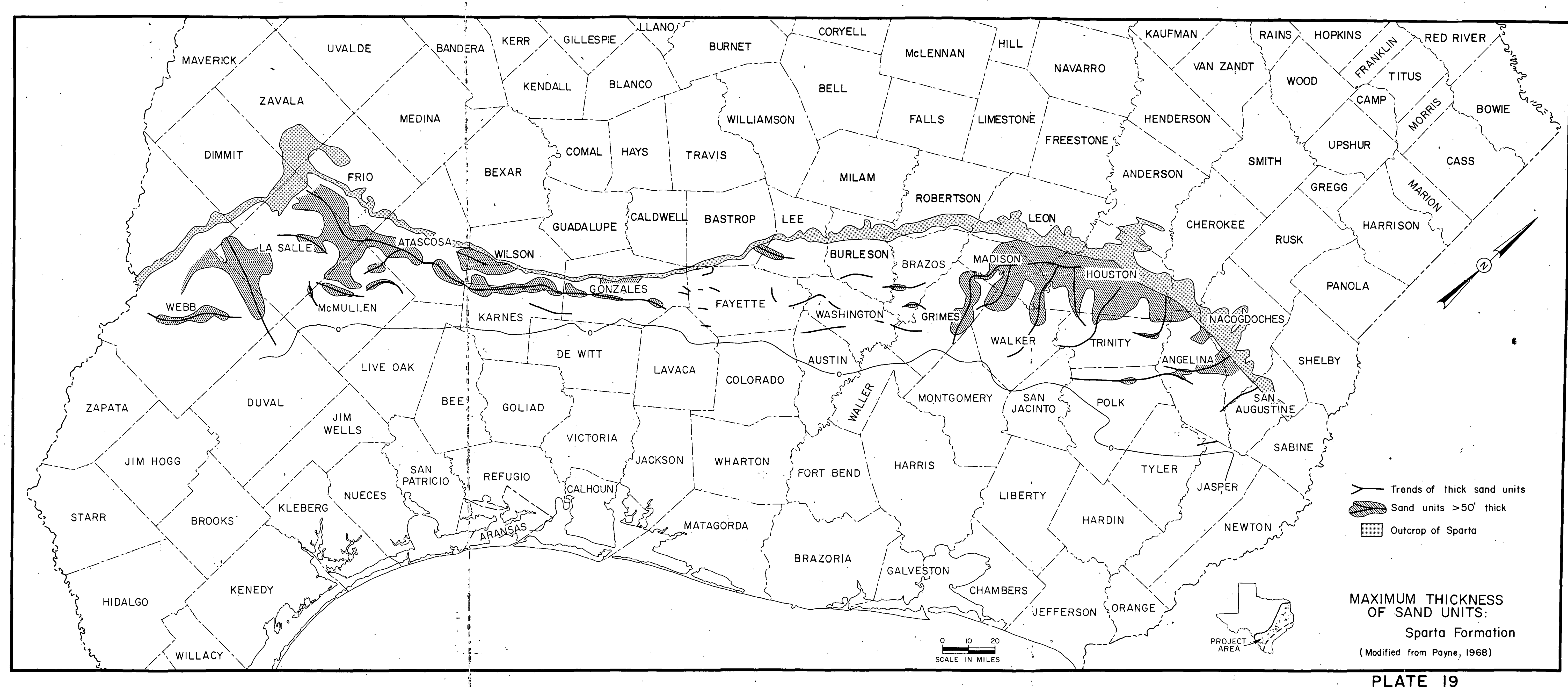

PLATE 19 